\title{
OPTIMIZATION OF 2-STAGE TURBOCHARGED GAS SI ENGINE UNDER STEADY STATE OPERATION
}

\section{OLDŘICH VITEK, JAN MACEK}

Czech Technical University in Prague Josef Božek Research Center Technická 4, 16607 Prague 6, Czech Republic, Tel.: +420 224352 507, E-mail: oldrich.vitek@fs.cvut.cz

\section{JIŘí KLÍMA, MARTIN VACEK}

PBS Turbo Velká Bíteš

\section{ABSTRACT}

The proposed paper deals with an optimization of a highly-turbocharged large-bore gas SI engine. Only steady state operation (constant engine speed and load) is considered. The paper is mainly focused on theoretical potential of 2-stage turbocharging concept in terms of performance and limitation. The results are obtained by means of simulation using complex 0-D/1-D engine model including the control algorithm. Different mixture composition concepts are considered to satisfy different levels of $\mathrm{NO}_{x}$ limit - fresh air mixed with external cooled EGR is supposed to be the right approach while optimal EGR level is to be found. Considering EGR circuit, 5 different layouts are tested to select the best design. As the engine control is relatively complex (2-sage turbocharger group, external EGR, compressor blow-by, controlled air excess), 5 different control means of boost pressure were considered. Each variant based on above mentioned options is optimized in terms of compressor/turbine size (swallowing capacity) to obtain the best possible BSFC. The optimal variants are compared and general conclusions are drawn.

KEYWORDS: INTERNAL COMBUSTION ENGINE, MATHEMATICAL MODELING, 0-D/1-D CFD, 2-STAGE TURBOCHARGING, $\mathrm{NO}_{\mathrm{x}}$ LIMIT, TA LUFT, EGR, DIFFERENT BMEP CONTROL MEANS

\section{SHRNUTÍ}

Práce se zabývá optimalizací vysoce přeplňovaného velkého plynového zážehového motoru. Pouze ustálené režimy (konstantní otáčky a zátěž) jsou uvažovány. Článek je primárně zaměřen na teoretický potenciál dvoustupňového přeplňování z hlediska dosažených parametrů a omezení. Výsledky byly získány pomocí komplexního 0-D/1-D modelu motoru včetně rídícího algoritmu. Různé koncepce složení směsi jsou uvažovány pro dosažení rủzných limitů pro $\mathrm{NO}_{x}$ - předpokládá se, že správný přistup zahrnuje mísení čerstvé směsi s EGR a hledá se optimální úroveň EGR. Co se týká EGR, tak je testováno celkem 5 variant okruhů EGR, ze kterých se vybírá nejlepší varianta. Protože řizení motoru je relativně komplexní (dvoustupňová plnicí skupina, vnější EGR, přepouštění na straně kompresoru, přebytek vzduchu), je testováno 5 různých způsobů rízení plnicího tlaku. Každá varianta založena na výše uvedených konfiguracích je optimalizována z hlediska velikosti kompresoru/turbiny (hltnost) pro nejlepší měrnou spotřebu. Jsou porovnány optimální varianty a formulovány obecné závěry.

KLíČOVÁ SLOVA: SPALOVACI MOTOR, MATEMATICKÉ MODELOVÁNÍ, O-D/1-D CFD, DVOUSTUPÑOVÉ PŘEPLŇOVÁNÍ, LIMIT NO ${ }_{x,}$ TA LUFT. EGR, RŮZNÉ ZPU゚SOBY ŘíZENÍ BMEP

\section{INTRODUCTION}

Large-bore spark-ignited internal combustion engines (SI ICEs) are usually applied as a power source (e.g., electricity). The amount of applications has been increasing significantly in recent decades due to the fact that they can achieve diesel-like efficiency (over $40 \%$ of brake efficiency) while keeping pollutant formation at very low level - c.f. $[8,24,27,28]$. Such performance is achieved by application of lean mixture concept - air excess is relatively high (more than 1.8 at nominal operating conditions), which lowers both heat losses and $\mathrm{NO}_{x}$ formation while knock resistance is usually improved as well. However, the concept requires that a boost device is able to provide high amount of fresh air. This can be achieved by application 
of 2-stage turbocharger group. Theoretical potential of 2-stage turbocharging is relatively high provided that the turbochargers are properly matched with the target engine. Moreover, boost pressure control during fast transient load change is demanding. On top of that, it is expected that future emission limits will (most likely) require application of cooled external EGR concept as it is widely used in passenger cars. All these facts lead to a conclusion that such an engine will be relatively complex from design point of view which requires complex control as well. It is also obvious that close cooperation between ICE manufacturer and turbocharger manufacturer is needed to achieve an optimized design and a proper control.

History of 2-stage turbocharging concept is relatively old due to its application to $\mathrm{Cl}$ engines (c.f. $[5,6,10])$. Concerning $\mathrm{SI}$ engines, it is not the case due to well-known limitations of this engine type (e.g., knocking, uncontrolled auto ignition, high exhaust gas temperature). When considering large-bore SI engines only, the high efficiency single-stage turbochargers, which are able to provide boost pressure over 5.5 bar currently, were a sufficient solution for many decades. However, the recent trend, which requires lowering pollutant $\left(\mathrm{NO}_{\mathrm{x}}\right)$ formation while improving engine efficiency, enforces the application of the lean-burn concept in combination with non-standard engine cycle (Miller/Atkinson) while increasing engine BMEP (downsizing). This leads to requirement of very high boost pressure, which is beyond the ability of single-stage boost systems. Hence, the worlds first commercial application of 2-stage boost group to a large-bore lean-burn gas SI engine was implemented only recently - in 2010, Jenbacher J624 engine was introduced in a 2-stage configuration (c.f. [28]). There are other 2-stage turbocharged engines being developed by major large-bore SI engine manufacturers (c.f. $[3,8,24,27]$ ) while different ignition concepts are considered - classical spark ignition, application of pre-chamber (scavenged version or local fuel enrichment design) or dual fuel approach.

Application of high efficiency boost group (total peak efficiency of 2-stage turbocharger group, which was applied in this paper, is $73 \%$ - this value was measured at turbo test rig while running both stages together; moreover, special design HP turbocharger was applied - the design is optimized for 2-stage application) provides high potential for improving both ICE efficiency and engine transient response. It is well-known that turbocharger efficiency is a critical factor in terms of engine BSFC, hence there is always a need to improve it as much as possible c.f. $[4,11,33,34,36]$. Moreover, if high values of boost pressure are achievable, non-standard thermodynamic engine cycle can be applied (early/late IVC, which is usually known as Miller/Atkinson thermodynamic cycle). Such cycles allow to decrease effective compression ratio while preserving high expansion ratio - this has a positive effect on both $\mathrm{BSFC}$ and $\mathrm{NO}_{x}$ level of an $\mathrm{SI}$ engine (c.f. $[9,12,23,24,26,27])$.

When dealing with requirement to lower $\mathrm{NO}_{x}$ level, there are different technologies available - lowering engine compression ratio, increasing air excess, application of cooled external EGR, advancing combustion towards BDC (late combustion), application of exhaust SCR system, etc. Each of them has its own advantages and disadvantages, moreover there is usually a cost and/or BSFC penalty associated with that. For the case of large-bore gas $\mathrm{SI}$ engine, there is an interesting possibility to combine high efficiency boost group with non-standard thermodynamic cycle (early IVC - Miller cycle) and possibly with cooled external EGR to significantly decrease $\mathrm{NO}_{x}$ while preserving low BSFC (very low BSFC penalty).

The presented paper deals with theoretical potential of 2-stage turbocharged gas $\mathrm{SI}$ engine in terms of $\mathrm{BSFC}$ and $\mathrm{NO}_{x}$ level. The presented work is a part of larger project (national grant of Technological Agency of the Czech Republic, Project TA03011212) which deals with development of 2-stage turbocharger boost group for large-bore ICE applications. The results presented in the paper deal with gas SI engine under steady state operation with fixed valve train parameters.

\section{MAIN GOALS}

The main target was to evaluate steady state performance of large-bore $\mathrm{SI}$ engine in terms of different engine control, different EGR route configurations, different EGR levels and different $\mathrm{NO}_{\mathrm{x}}$ levels. The results were obtained by means of detailed thermodynamic simulation. Influence of each factor (engine control, EGR route configuration, applied EGR levels and required $\mathrm{NO}_{x}$ levels) was evaluated by means of sensitivity study - only one parameter was varied while all other ones were kept constant. The evaluation of results is performed by means of relative comparison of tested variants.

Based on that, the following additional goals were set:

- Optimize each variant in terms of turbocharger matching while minimizing BSFC under steady state operation at rated engine load (c.f. Table 1).

- Compare different engine control means in terms of BSFC.

- Compare different configurations of EGR circuit and select the best variant(s).

- Evaluate the influence of required EGR rate with respect to BSFC.

- Evaluate the influence of required $\mathrm{NO}_{\mathrm{x}}$ level (defined by means of TA Luft norm) in terms of BSFC.

- Propose optimal engine concept in terms of EGR rate and EGR route configuration at different $\mathrm{NO}_{\mathrm{x}}$ levels while BSFC is minimal. 
TABLE 1: Main engine parameters.

TABULKA 1: Hlavní parametry motoru.

\begin{tabular}{lcc|}
\hline $\begin{array}{l}\text { Engine Parameter } \\
\text { Bore-to-Stroke Ratio }\end{array}$ & Unit & Value \\
\hline Compression Ratio & {$[1]$} & 0.8636 \\
\hline Charging & {$[1]$} & 14 \\
\hline Fuel & & 2-stage Turbocharged \\
\hline Number of Intake Valves & Methane \\
\hline Number of Exhaust Valves & & 2 \\
\hline Rated BMEP & {$[\mathrm{bar}]$} & 2 \\
\hline Mean Piston Speed & {$\left[\mathrm{m} . \mathrm{s}^{-1}\right]$} & 24 \\
\hline
\end{tabular}

It should be stressed that an optimization/development of a specific engine was not a primary goal of the work. The paper is mainly about theoretical potential of 2-stage turbocharging for the case of lean-burn gas SI engine concept. As the large project has been done in cooperation with a turbocharger manufacturer, the main focus is put on performance and limitation of 2-stage turbocharging concept, hence the interaction between an engine and a boost group is of main interest. It is well-known that selected engine concept, layout of important pipe systems and BMEP control strongly influence a requirement of boost pressure. Extreme cases ware tested while maintaining high BMEP requirement (c.f. Table 1) - very high EGR rates, very low $\mathrm{NO}_{x}$ levels. Different EGR configurations and different boost pressure control ware analyzed. This enables to evaluate the theoretical potential of the 2-stage turbocharging concept in terms of possible future applications, which is very important for a turbocharger manufacturer.

\section{EN GINE MODEL}

It was already mentioned that all results presented in the paper were obtained by means of simulation. Sensitivity studies were performed and relative comparison of tested variants was done. Extreme cases in terms of EGR and/or $\mathrm{NO}_{x}$ level were evaluated, which may require very high boost pressure. Such simulation requires a reliable calibrated model as many operating conditions, which were tested by simulation approach, cannot be verified on an existing engine. However, the target engine (c.f. Table 1) does not exist and limited amount of data were available from measurement when similar engine was experimentally verified. All these facts lead to a statement that the applied engine model corresponds to a virtual engine which is defined by means of limited experimental knowledge and experience of the authors with similar engines (i.e., large-bore lean-burn gas SI ICE). This may limit the quality of the prediction in terms of quantities, however, the qualitative trends are supposed to be captured properly if correct modelling approach was adopted. This mainly concerns the application of predictive submodels. Moreover, the relative comparison of considered variants was done this means that only the differences among tested cases were considered, hence possible modelling errors are compensated. Such approach can provide only qualitative conclusions.

The engine model was build in GT-Power 0-D/1-D code [1] which enables to simulate the whole engine cycle including exhaust gas energy transfer between the cylinders and the turbocharger. Main engine parameters are summarized in

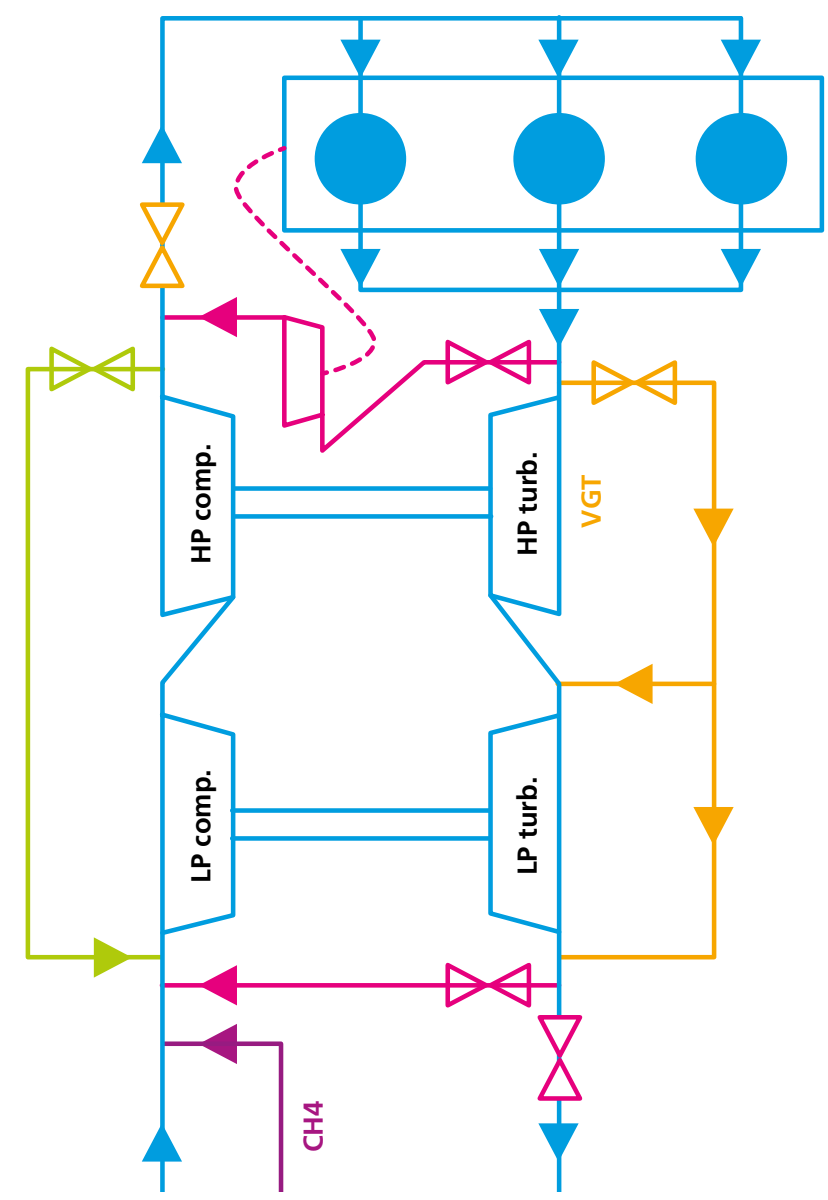

- Air excess control:

- based on free oxygen (including EGR)

BMEP control:

- intake throttle

- compressor blow-by ('green' path)

- waste-gate (2 variants)

- variable geom. turbine (VGT)

Compressor blow-by control:

- customer requirement ( tv5\%)

- compressor surge

External cooled EGR control:

- EGR valve eff. area

- dedicated EGR compressor driven by electric motor

- exhaust throttling (if needed)

FIGURE 1: Engine layout with main control circuits (all considered EGR variants are plotted in Figure 5).

OBRÁZEK 1: Konfigurace motoru včetně řídících okruhů

(všechny uvažované EGR varianty jsou vykresleny na Obrázku 5). 
Table 1, the engine layout is shown in Figure 1. The engine model is based on existing engine of unspecified manufacturer. Only limited knowledge of the target engine parameters was available, hence unknown information was estimated by the authors using experience with similar engines $[15,25,29$, 32]. The turbocharger manufacturer was able to get some experimental data from engine manufacturer. These data concern the reference engine which is the same as the target engine (Table 1), however, it is equipped with different boost group. Unfortunately, there is not sufficient information to perform a calibration of all important submodels. Moreover, there are some uncertainties regarding important engine operating conditions of the measurement. Based on that, the engine model is based mainly on previous experience with similar engine (internal reports $[30,31]$ - the model was updated taking into account only reliable information from reference engine measurement. The engine head has 4 valves -2 intake valves and 2 exhaust valves. The valve lifts and the flow discharge coefficients are based on previous experience (internal reports [30, 31]). The geometry model is based on limited knowledge of the target engine.

Concerning combustion model, no experimental data were available. Simple Vibe function model was applied using the previous experience (internal reports $[30,31]$. When not stated otherwise, the combustion duration and timing are constant regardless of engine load, air excess and EGR level. This is obviously simplification, however, results presented in [37] show almost no sensitivity of ROHR with respect to increased external EGR (c.f. Figure 19). On the other hand, it should be stated that relatively low EGR rates were tested (up to $10 \%$ ) and different ignition system (pre-chamber) was applied. Based on all facts, the authors are convinced that application of non-predictive combustion model has minor influence on optimization of boost group and selection of both proper control and the best EGR configuration. More details to support this statement are presented in Appendix.

When performing sensitivity studies, it is necessary to apply models which have predictive ability. Therefore the following models were applied. Simplified finite element (FE) model, which is based on papers $[13,20]$, is used to calculate combustion chamber temperatures while Woschni formula (c.f. [38]) was applied to estimate the heat transfer coefficient between the in-cylinder gas and the walls (boundary condition for FE model). The simplified FE model is the standard built-in model (labelled 'EngCylTWallSoln') in the commercial code [1] - it calculates temperatures of combustion chamber (liner, piston, head, valves, etc.) based on simplified geometry model and material properties. The advantage of the model is that it can predict wall temperatures based on engine operating conditions, however, both the FE model and the Woshni one need calibration to provide quantitatively correct results. All necessary model constants were estimated by the authors - they are based on previous experience (internal reports [30, 31]. Mechanical efficiency was calculated using GT-Power formula based on Chen-Flynn model [7], which includes dependency on engine speed, engine square speed and in-cylinder maximum pressure.

Regarding intercooler models (LP and HP), they were built in such a way that outlet fluid temperature was constant (taking into account the temperature of water cooling system dedicated to intake air cooling) while pressure loss at nominal power is approximately $3-5 \mathrm{kPa}$. By doing this, large and quite efficient intercooler was modelled. EGR cooler model was created in a similar way, however, cooler wall temperature is calculated based on cooler geometry and outer boundary condition (of cooling water temperature).

After a base engine model had been created, the following major modifications were done so that the main targets could be achieved:

- Different EGR systems were added to the model

(c.f. Figure 1 and Figure 5). Each EGR circuit consists of EGR valve, piping and EGR cooler. Prescribed EGR rate is of linear dependency on engine load (subFigure (e) of Figure 14) while the label in the text and figures corresponds to maximal EGR requirement (which is for BMEP 24 bar). The expected linear dependency was estimated by the authors to take into account the fact that $\mathrm{NO}_{x}$ formation strongly depends on temperature which is expected to decrease when engine load is decreased.

- Application of $\mathrm{NO}_{x}$ model which considers Zeldovich kinetic mechanism of $\mathrm{NO}_{x}$ formation [39]. Details can be found below in Chapter 3.2.

- Control algorithms of all necessary components which need to be actuated/controlled during the simulations (e.g., compressor by-pass (blow-by), waste-gate, intake throttle, air excess based on experimental data or $\mathrm{NO}_{x}$ level, HP VGT, EGR valve, EGR exhaust throttle, EGR compressor gear ratio). Required air excess is based on experimental data or it is controlled to achieve requested level of $\mathrm{NO}_{x}$, which is defined by means of TA Luft multiplier - the value of 1.0 means that $\mathrm{NO}_{\mathrm{x}}$ level corresponds to the limit defined by TA Luft norm while the value of 0.25 requires that $\mathrm{NO}_{\mathrm{x}}$ level has to decrease to $25 \%$ of TA Luft norm.

It should be stressed that no knocking or auto-ignition were taken into account. Moreover, little was known about valve timing. It was estimated by means of using limited available experimental data and authors experience. Concerning IVC, 
it is expected that Miller cycle is adopted - sensitivity study suggested that relatively strong Miller cycle is applied (IVC, which is defined by $1 \mathrm{~mm}$ lift, at 55CAdeg BBDC). Many modern large-bore ICEs adopt Miller/Akinson cycle to limit maximum in-cylinder pressure and/or $\mathrm{NO}_{\mathrm{x}}$ level while preserving high expansion ratio to obtain low BSFC (c.f. $[9,12,23,24,27,28])$, however, such approach requires high efficiency boost group.

\subsection{TURBOCHARGER MODEL}

Concerning turbocharger maps, the standard approach was adopted. This means an application of lumped compressorl turbine model(s) using standard maps provided by turbocharger manufacturer. However, the turbocharger manufacturer provided data based on measurement of the whole boost group, which means that both turbochargers were measured simultaneously. It was found that efficiency of HP turbocharger is increased when compared with measurement data of single stage turbocharger only. This is a slightly surprising result, however, the experts from the turbocharger manufacturer explain that by relative decrease of losses when turbocharger is heavily loaded thanks to LP stage, which enables density increase at HP compressor/turbine inlet. This fact, which is based on experimental data, had to be taken into account in the simulation as well. After some discussions with people from the turbocharger manufacturer, it was decided that efficiency multipliers will be applied to HP compressor/turbine using data from experiments this is plotted in Figure 2. At that time, it was not obvious what was a correct parameter which was supposed to determine efficiency scaling. The HP compressor inlet density was selected to be the marker for efficiency

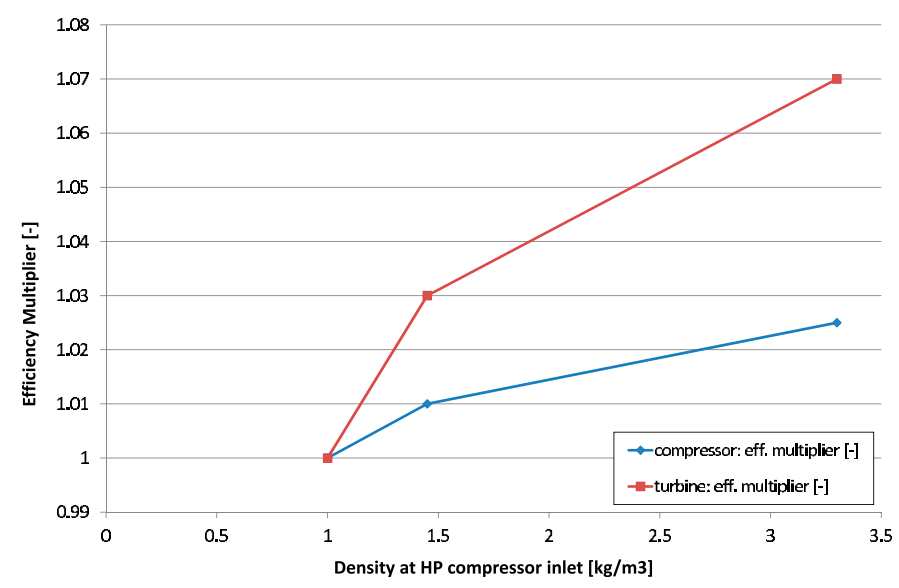

FIGURE 2: Efficiency multipliers of HP turbocharger based on measurements at the turbocharger manufacturer when the whole boost group (HP stage + LP stage) was tested.

OBRÁZEK 2: Násobitele účinnosti pro vysokotlaké turbodmychadlo založené na měřeních u výrobce, kdy byla testována celá plnicí skupina (tj. nízko- i vysokotlaký stupeň). scaling (it is plotted on horizontal axis of Figure 2). It should be stressed that efficiency increase at high inlet density, which corresponds to high mass flow rate, is relatively significant especially for HP turbine.

Final comment concerns possible application of 1-D radial turbine model which was developed at CTU. The model is based on [14,16-18] and it was successfully applied in a case of fixed geometry turbine for heavy duty diesel engine and for VGT turbine for medium duty diesel engine. Such model has predictive capability based on 1-D CFD - it can be applied to extrapolate turbine maps or improve turbine model performance under strongly unsteady conditions (including engine transient response). However, the authors doubt that it can predict efficiency increase which was measured (Figure 2). Additional measurements are planned for the future and it would be of advantage if 1-D turbine model can be created and successfully calibrated to improve overall simulation accuracy.

\section{$3.2 \mathrm{NO}_{x}$ MODEL CALIBRATION}

Applied $\mathrm{NO}_{x}$ model is a simple model which is based on multi-zone approach and well-known Zeldovich mechanism [39]. The model is a standard built-in one (object 'EngCyINO ${ }_{x}$ ') and it needs to be calibrated with respect to experimental data. The calibration was done using data provided by the turbocharger manufacturer for engine power output in the range from $20 \%$ to $100 \%$ of rated power (c.f. Figure 3 ). Reasonable correspondence between measurement and prediction was achieved by means of calibrating only one tuning constant of the model. Similar approach was successfully adopted in previous work (internal report [31] c.f. Figure 4). The $\mathrm{NO}_{x}$ model main calibration parameter $\left(\mathrm{NO}_{x}\right.$ Calibration Multiplier) is set to the value of 4.448 , which is exactly the same value as in the case of internal report [31]. All other calibration parameters remain at their default values. However, it seems that the simple calibration leads to overestimation of $\mathrm{NO}_{x}$ for the low engine load range which leads to a necessity to increase air excess (when compared with measured data) in order to satisfy $\mathrm{NO}_{x}$ limit (TA Luft at $100 \%$ level).

Predicted engine efficiency is slightly lower and boost pressure is slightly higher when compared with existing experimental data. This is most likely caused by the fact that the boost group is different (the measurement was performed using turbomachinery of another manufacturer) and a lack of experimental results (in-cylinder pressure, intercooler pressure loss, detailed geometry information, intake/exhaust valve lift/discharge coefficient, etc.), which forced the authors to estimate them using the modelling experience with similar 
engines. However, the qualitative trends are similar, hence the engine model calibration is considered to be satisfactory taking into account main goals of the paper. On the other hand, the predicted air excess curve has clearly different slope when compared with experimental values - this is not inline with experience gained during previous project (internal report [31] c.f. Figure 4).

Different sensitivity studies were performed to find the reason why $\mathrm{NO}_{x}$ prediction is poor under low engine load conditions. It was found that calibration constants of the model cannot change the slope of predicted air excess (red curve in Figure 3) - they can only shift the curve. The same applies to a case when IVC event was varied - this leads to

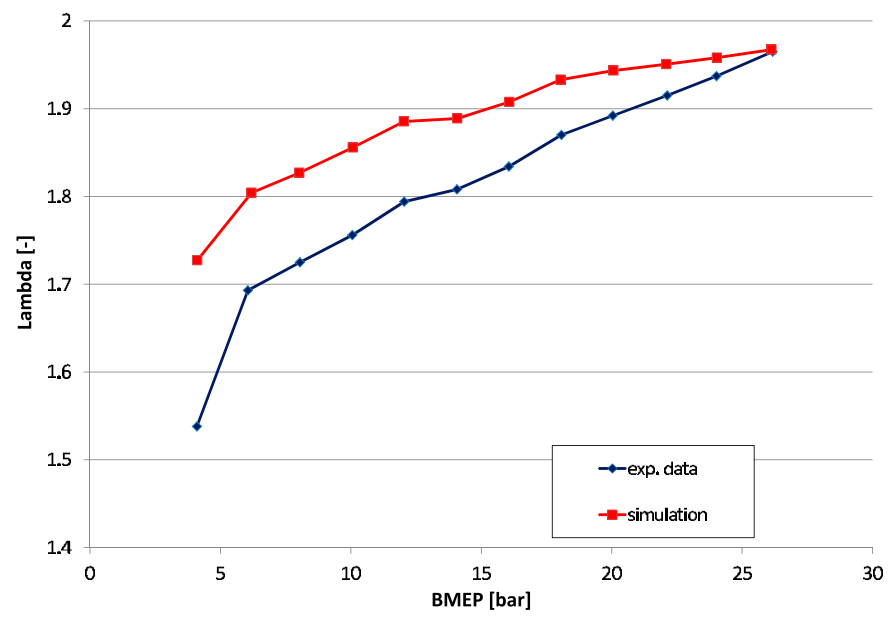

FIGURE 3: Reference engine: comparison of measured and predicted air excess at constant NOx level (TA Luft $=100 \%$ ).

OBRÁZEK 3: Referenční motor: srovnání naměřených a vypočtených hodnot prebytku vzduchu pro konstantní úroveň NOx (TA Luft = 100\%).

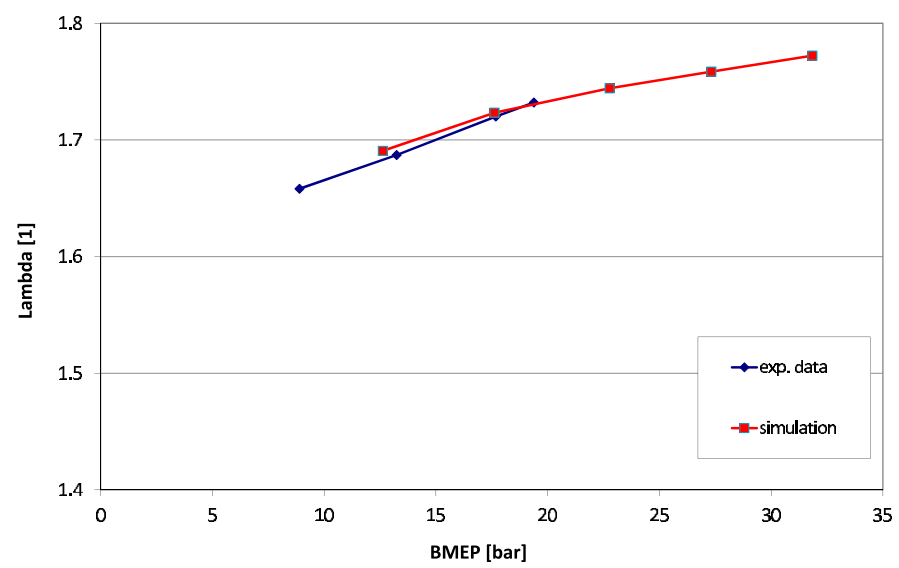

FIGURE 4: Similar large-bore lean-burn gas SI engine: comparison of measured and predicted air excess at constant NOx level (TA Luft $=100 \%)$.

OBRÁZEK 4: Podobný velký plynový zážehový motor: srovnání naměřených a vypočtených hodnot přebytku vzduchu pro konstantní úroveň NOx (TA Luft = 100\%). curve shifting while the slope is changed only marginally. All the facts indicate that more sophisticated combustion model is needed to properly predict $\mathrm{NO}_{\mathrm{x}}$ level at different engine load. Moreover, it is expected that external EGR is supposed to be applied to meet strict emission limits - this also calls for application of advanced combustion model. However, there are not enough experimental data to calibrate such model, hence it was decided not to do that. More details regarding applied combustion model can be found in Appendix.

Final comment of $\mathrm{NO}_{\mathrm{x}}$ model calibration is that the model is reasonably well calibrated under high engine load (BMEP $\approx 24$ bar) and high air excess $(\approx 1.9)$, hence optimizations can be performed at this load/air excess levels while using simple combustion model (constant combustion duration and phasing). The authors also expect that qualitative trends are supposed to be captured properly even for the case of external EGR application. If quantitatively correct prediction is needed, the application of the advanced combustion model is supposed to be necessary - this mainly concerns cases with different engine load and/or different air excess and/or possibly non-zero external cooled EGR level.

\section{COMPUTED CASES}

The main target of the paper was to optimize boost group (2-stage turbocharger system including its control + external cooled EGR system) of large-bore gas SI engine under steady operation. To achieve that, different types of simulations were performed:

- Standard steady state simulations were carried out at different engine power levels (approximately between $20 \%$ and $100 \%$ of rated power). The target was to obtain a steady-state solution of all important engine parameters.

- Fine-tuning simulations were carried out to find reasonable constants of the controllers to achieve converged results while all required targets were met. This was actually challenging task as there are usually multiple controllers active during the course of the simulation to achieve different targets simultaneously (BMEP, air excess, compressor blow-by, $E G R)$. Hence, the instability of a single controller leads to oscillations of the remaining ones. Moreover, the dynamic behavior of the whole engine is significantly changed when different turbochargers are applied. Different control strategies are also important. Hence, a lot of simulations were carried out to verify stable model performance so that the optimizations can provide correct answers - in other words: if controller performance leads to instability, the results are not 
converged, hence the performance targets are not met which may lead to dropping potentially promising design, which has to be avoided.

- Multi-variable optimizations under steady conditions at maximum required power (Table 1) were performed. Details about the applied optimization procedure can be found below in Chapter 4.3. The target of the optimization was to minimize BSFC while taking into account limiting conditions (e.g. required engine power, air excess, compressor blow-by, EGR). Typically, the following parameters were optimized -4 multipliers of HP/LP compressor/turbine maps to find the best possible turbocharger combination. Different control strategies, different EGR configurations, different EGR levels and different $\mathrm{NO}_{x}$ levels were considered.

As the paper is mainly focused on theoretical potential of 2-stage boost concept in terms of possible future applications (c.f. Chapter 2), the main outputs of the optimization procedure were mass flow multipliers of HP/LP compressor/ turbine. This means that 2-stage boost group performance was verified under extreme cases of high $E G R$, very low $\mathrm{NO}_{x}$ level while considering different EGR configurations and/or different boost pressure control.

If the engine was the main focus, which was not the case, then important engine design parameters would be optimized this would concern engine compression ratio, all valve timing events with the special focus on IVC, combustion phasing, etc.

\subsection{DIFFERENT ENGINE POWER CONTROL MEANS}

The original engine is controlled by means of throttle located downstream of HP intercooler. This control is considered to be the default one, hence if there is no specific label of applied control, the default one was considered. It is labelled in figures and in the paper text as throttle. The throttle control is a standard approach to control SI engine power output, however, it is well-known that it is not the optimal one in terms of BSFC. Based on that, other possibilities were considered to quantify potential of BSFC improvement - it should be stressed that the different control means are evaluated from thermodynamic point of view only (no reliability/safety/cost reasons are considered).

The engine was equipped by a compressor by-pass, which is labelled blow-by. It connects HP pipe system (the inlet of blow-by system is located downstream of HP intercooler) with the LP one (outlet of blow-by system is positioned upstream of LP compressor). The main reason of the system is to have additional power margin with respect to intake system clogging. Initially the blow-by system is open (the amount of mass flow rate is approx. $5-8 \%$ of engine fresh air flow). Once the intake pipe system pressure losses are increased, the blow-by valve is being closed to keep engine power at the required level. Once the blow-by valve is fully closed, the engine service is required to clean the whole intake pipe system. It is obvious that application of the blow-by is a loss from thermodynamic point of view, however, it is a convenient solution to increase engine service intervals. It is obvious that the system can be applied to control engine power, hence it was considered as a possible engine control mean. From thermodynamic point of view, the compressor blow-by leads to decrease of effective turbocharger efficiency, hence it can easily control boost pressure.

Other possibility is the classical waste-gate approach. The boost pressure is controlled via taking control of turbine power. In the case of 2-stage boost group, there are 2 possibilities. The first one concerns waste-gating of HP stage only - such variant is labelled WG_HP_only. The second possibility consists of by-pass of both turbine stages and it is labelled WG. It is obvious that waste-gating causes some thermodynamic losses.

Final possibility, which is considered in the report in terms of engine power control, is variable geometry turbine (VGT) at HP stage. Such variant is labelled as fict_HP_VGT. The authors are aware of the fact that the turbocharger manufacturer does not consider (at the time of writing the paper) the option to offer HP turbine as a VGT one, hence the label 'fict', which represents fictitious possibility. Moreover, the swallowing capacity of VGT turbine was increased towards higher mass flow rates. This was done due to the fact that certain engine operating conditions require such large turbine, which is not available in reality. This was done to be able to apply the correct HP turbine size in all cases. The fict_HP_VGT is considered purely from thermodynamic reasons as it represents the control mean with the lowest thermodynamic loss when compared with all above mentioned control variants.

Based on the text above, 5 different control means are considered. All these variants were fully optimized under different operating conditions to evaluate influence on BSFC. The control stability is also important - certain variants are causing relatively large changes of thermodynamic properties in intake/exhaust HP pipe system(s) which leads to oscillations and possible issues with respect to engine control.

\subsection{DIFFERENT EGR ROUTES}

The target engine was supposed to be equipped with external cooled EGR system to satisfy more strict limits ( $T A L u f t$ ) in terms of $\mathrm{NO}_{x}$ formation. Different EGR routes were examined to evaluate their potential in terms of BSFC penalty due to pressure losses in EGR pipe system. Exhaust gas cooling 


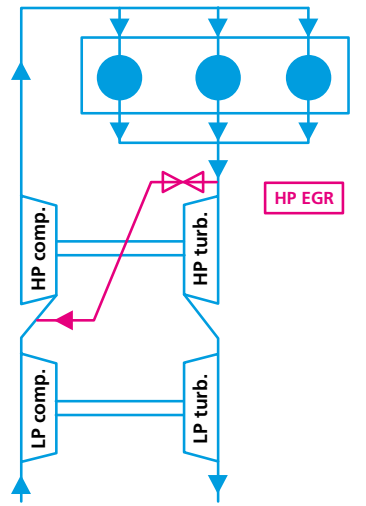

(a) high-pressure EGR (label HP EGR)

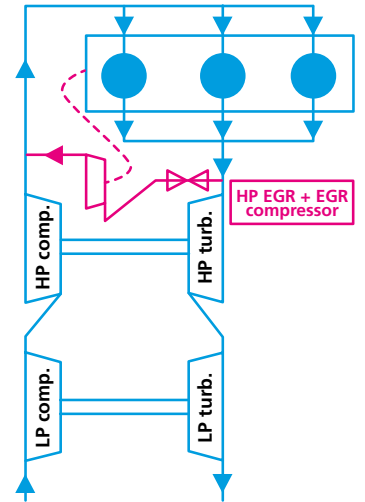

(b)high-pressure EGR + dedicated EGR compressor (label HP EGR + EGR compressor)

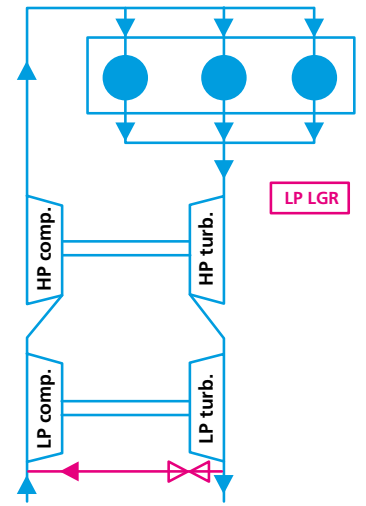

(c) low-pressure EGR (label LP EGR)

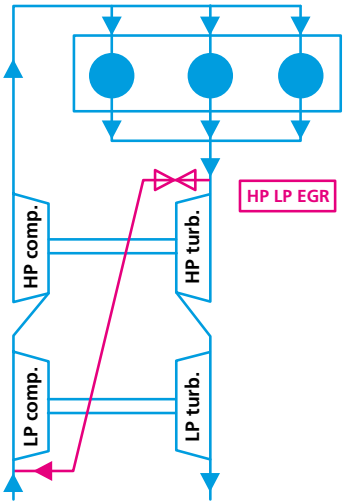

(d) combined high-low-pressure EGR (label HP-LP EGR)

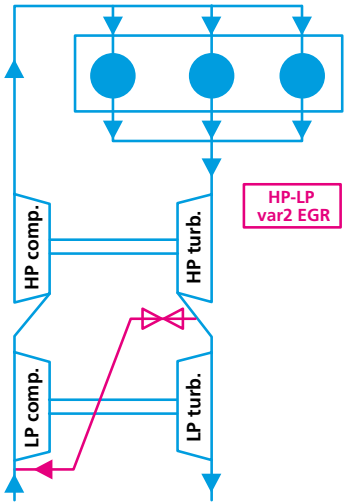

(e) combined high-low-pressure EGR var. 2 (label HP-LP var. 2 EGR)

FIGURE 5: Comparison of different EGR configurations and their labelling; there is an exhaust throttle located downstream of LP turbine which is activated whenever the EGR valve is fully opened while EGR requirement is not satisfied.

OBRÁZEK 5: Srovnání různých konfigurací EGR okruhů a jejich označení; za nízkotlakou turbinou je umístěna výfuková škrticí klapka, která se aktivuje kdykoliv je EGR ventil naplno otevřen a přitom není dodržena požadovaná hodnota EGR.

was achieved in EGR cooler. The considered variants are schematically plotted in Figure 5. The EGR rate is controlled via EGR valve - when it is not sufficient, which means that EGR valve is fully opened while EGR requirement is not met, the exhaust throttle flap (located downstream of LP turbine) is being closed to increase pressure level in the exhaust system. It is obvious that such exhaust throttling leads to significant increase of engine BSFC, hence it should be avoided whenever it is possible.

The standard approach is to apply high-pressure EGR circuit which connects HP turbine inlet with HP compressor outlet - this is not possible in this case as boost pressure is significantly higher than exhaust back pressure due to high efficiency of the whole 2-stage boost group. Hence, the high-pressure EGR variant (label HP EGR) connects HP turbine inlet with HP compressor inlet - it is plotted in subFigure (a) of Figure 5. The obvious disadvantage of this variant is non-equal mass flow through HP turbocharger as compressor mass flow is higher than turbine one.

Other possibility is to use low-pressure EGR system which connects LP turbine outlet with LP compressor inlet - such variant (labelled LP EGR) is shown in subFigure (c) of Figure 5. The advantage of the system is that it uses natural pressure losses in the pipe systems. However, exhaust pressure loss is relatively low for this large-bore SI engine (unlike in the case of automotive ICEs equipped with exhaust gas aftertreatment devices). This leads to low amount of maximum achievable $E G R$, hence exhaust throttling might be needed when EGR requirement is high. There is one significant advantage of $L P$
EGR system - compressor/turbine mass flow is not negatively affected by required EGR rate.

There are other 2 possibilities of combined EGR systems which connect exhaust pipe with intake one. The variant labelled as HP-LP EGR is shown in subFigure (d) of Figure 5 while the variant labelled as HP-LP var. $2 E G R$ is shown in subFigure (e) of Figure 5. Based on experience from automotive applications [36], EGR systems with too high pressure difference are not suitable for low BSFC cases their advantage is in possibility to achieve high EGR rates while there is high BSFC penalty. This is mainly caused by non-optimal turbocharger performance due to non-equal mass flow rates of compressr/turbine and additional pressure losses caused by throttling in EGR system.

Finally, it was decided to take into account proper HP EGR variant. To achieve that, additional compressor, which is labelled dedicated EGR compressor, is needed to overcome higher pressure in intake system when compared with the pressure of exhaust system. This variant is labelled $H P$ $E G R+E G R$ compressor and it is shown in subFigure (b) of Figure 5. The obvious advantage is that compressor/turbine mass flow of both turbochargers is equal and there is no need of throttling at EGR valve as the EGR compressor is supposed to be powered by electrical motor, which is controlled in such a way that required EGR rate is achieved by using the right compressor speed. Disadvantage is the complexity of the system (additional compressor + its control is needed) and higher price. However, such system has potential to provide required very high EGR rate at relatively low BSFC penalty. 


\subsection{DESCRIPTION OF OPTIMIZATION PROCEDURE}

Optimization is an important target of any simulation project. Properly/reasonably calibrated ICE model can be optimized to achieve improvements in terms of ICE design and/or operation. It is important to create/apply properly designed optimization procedure to achieve required simulation targets.

In this particular case, there are at least 4 independent variables (compressor/turbine swallowing capacity of each turbocharger) and many limits (compressor surge, turbocharger overspeeding checks that required engine operation was reached in terms of $\mathrm{BMEP}, \mathrm{EGR}, \mathrm{NO}_{\mathrm{x}}$ level, air excess). The target is to minimize BSFC. Hence, it is a multi-variable multi-constraint single-target optimization. Genetic algorithm [2] was applied to find the optimal solution.

\section{(a) brake specific fuel consumption (detail)}

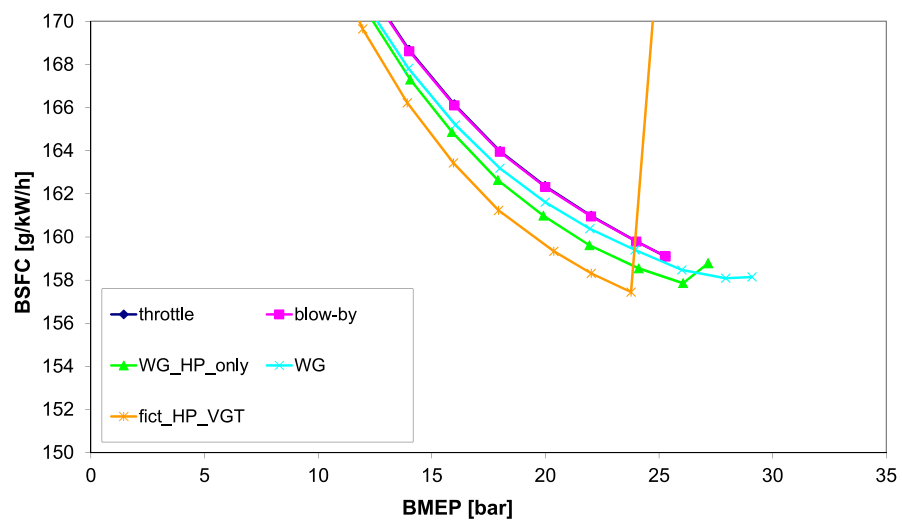

(b) pumping indicated efficiency

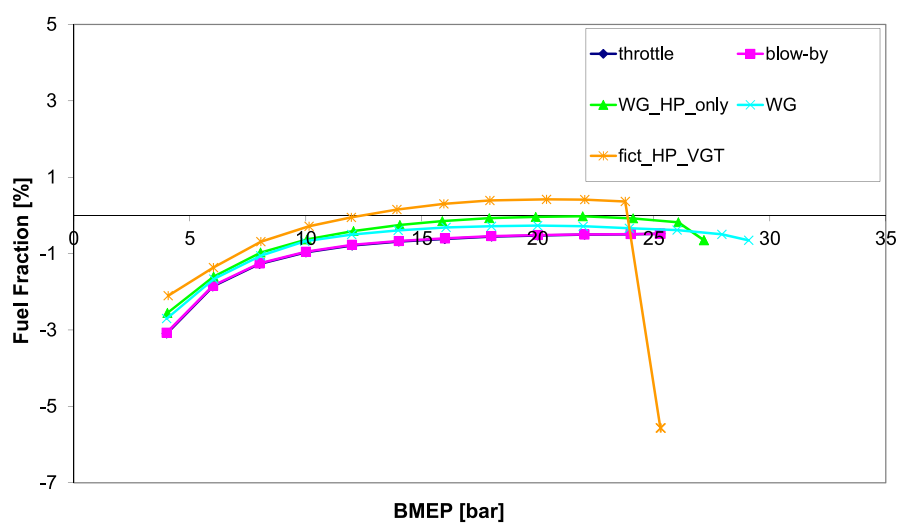

FIGURE 6: Comparison of different control means under steady operation - selected engine output parameters; engine setting: blow-by $=0 \%$, $E G R=0 \%$ (at BMEP $=24$ bar), prescribed air excess.

OBRÁZEK 6: Srovnání různých způsobů rízení motoru za ustálených podmínek - vybrané výstupní parametry motoru; nastavení: blow-by $=0 \%, E G R=0 \%$ (pro BMEP $=24$ bar), předepsaný průběh přebytku vzduchu.
Once the optimal design is found, ICE load curve (dependency of any parameter on engine load at constant engine speed) is calculated using the optimal setting - this setting is kept constant at any ICE operating point. As the optimization target is to find optimal turbocharger combination in terms of their swallowing capacity to minimize BSFC, the optimization procedure leads to optimal turbocharging matching for the case of considered engine configuration under given operating conditions (BMEP, EGR, blow-by, air excess, etc) all optimal results presented in the paper concern cases with $\mathrm{BMEP}=24$ bar (c.f. Table 1).

(a) brake specific fuel consumption (detail)

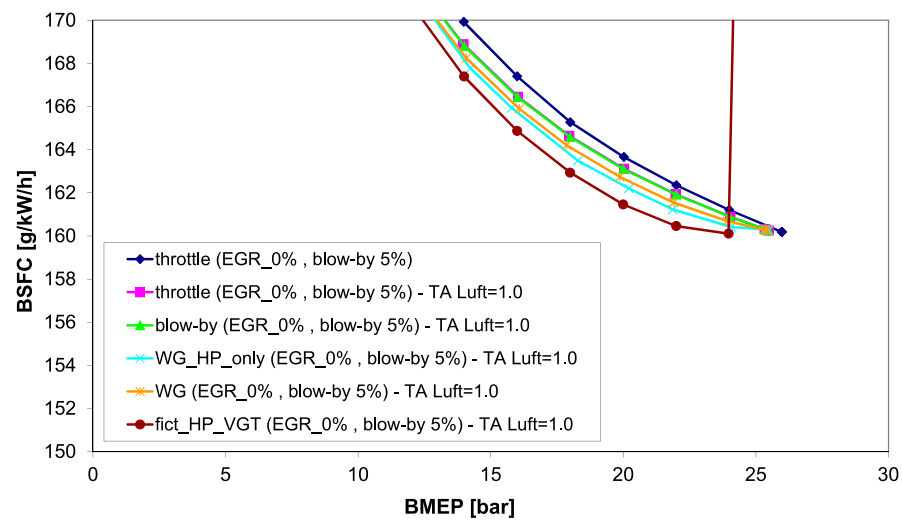

(b) pumping indicated efficiency

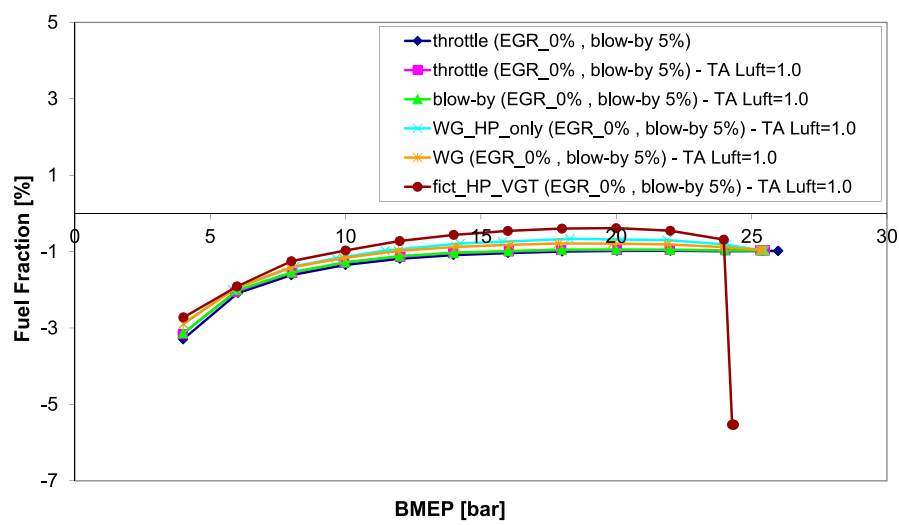

FIGURE 7: Comparison of different control means under steady operation - selected engine output parameters; engine setting: blow-by $=5 \%$, $\mathrm{EGR}=15 \%$ (at BMEP = 24 bar), prescribed air excess, HP EGR + EGR compressor.

OBRÁZEK 7: Srovnání různých způsobů rízení motoru za ustálených podmínek - vybrané výstupní parametry motoru; nastavení: blow-by $=5 \%, E G R=15 \%$ (pro BMEP = 24 bar), předepsaný průběh přebytku vzduchu, varianta HP EGR + EGR compressor. 
(a) HP compressor

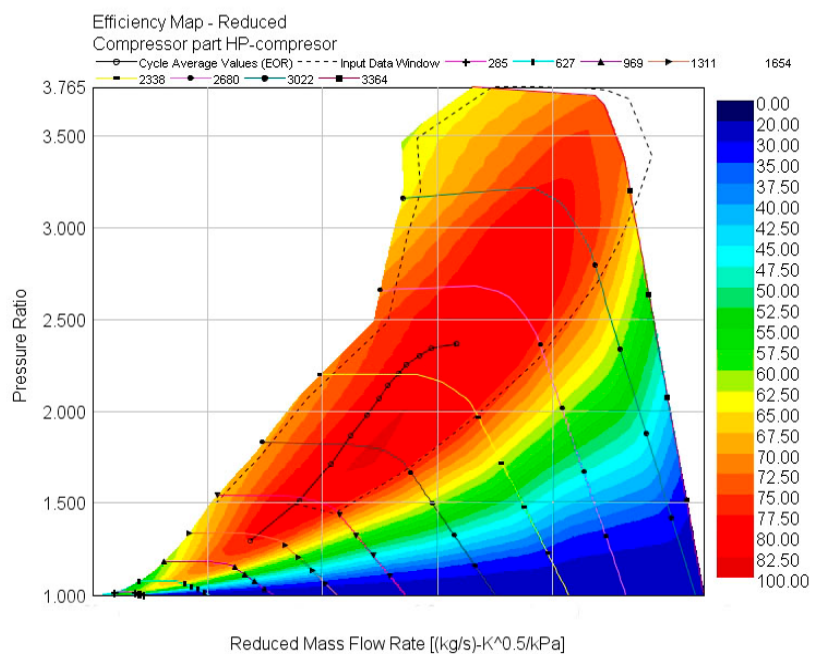

(c) HP turbine

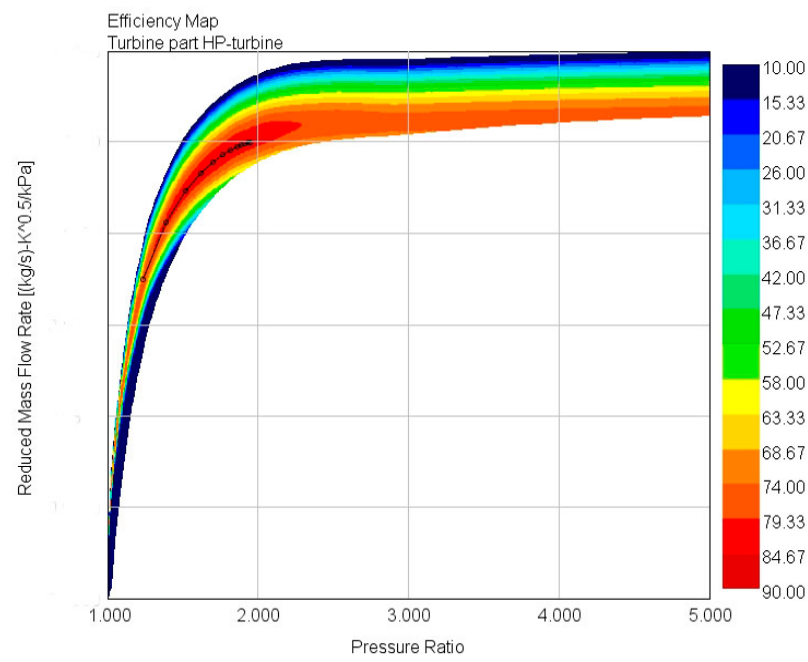

(b) LP compressor

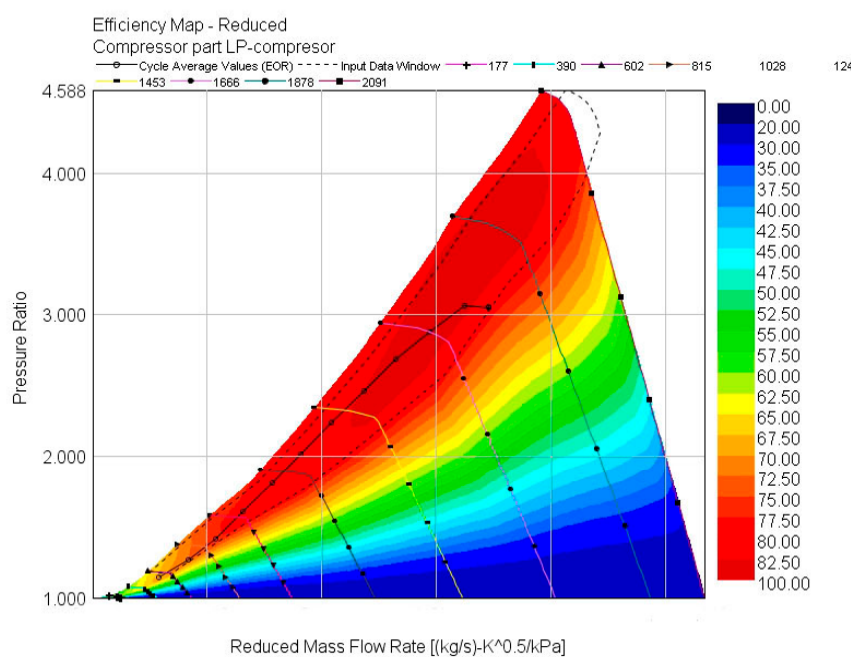

(d) LP turbine

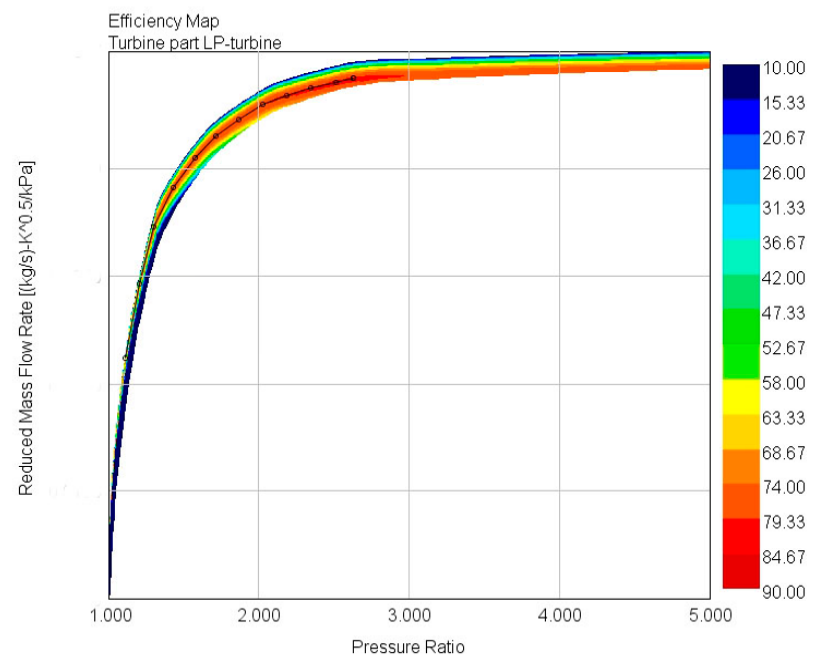

FIGURE 8: HP/LP compressor/turbine maps and operating curves corresponding to engine load curve of the variant throttle in Figure 6 (comment: dark blue curve represents the variant throttle in Figure 6, however, the curve coincide with pink curve of the variant blow-by in terms of BSFC and pumping work).

OBRÁZEK 8: Mapy vysoko- a nízkotlakého kompresoru a turbiny včetně pracovních křivek odpovídajícím zatěžovací charakteristice motoru pro variantu throttle z Obrázku 6 (poznámka: tmavě modrá křivka reprezentuje variantu throttle v Obrázku 6, která je ovšem totožná s růžovou křivkou odpovídající variantě blow-by z hlediska měrné spotřeby paliva a práce na výměnu náplně válce).

\section{DISCUSSION OF RESULTS}

The presented results are usually based on optimization of turbocharger sizes (mass flow multipliers) at BMEP=24 bar detailed description of optimization procedure is written above in the Chapter 4.3. After that, engine load data (BMEP is varied between 4 and 30 bar with increment of 2 bar) are calculated keeping constant parameters of the whole engine model while only certain control algorithms are active to satisfy BMEP, air excess, EGR, etc. Maximum calculated BMEP is set to 30 bar to check the potential of a considered variant to reach higher (than requirement in Table 1) power output levels.
Computed cases including labelling of considered variants are briefly described above in the Chapter 4 . The most important reasons are commented here to explain trends presented in figures. As there are many considered variants, the Figure description also informs about considered engine configuration (blow-by level, EGR level, $\mathrm{NO}_{\mathrm{x}}$ level, etc). The most important information is engine efficiency (BSFC) and the main reason of BSFC differences is usually pumping work, hence these 2 figures are typically shown for each considered case. If needed, additional figures might be presented to 
provide additional information. When concerning energy fluxes, they are normalized with respect to total fuel energy e.g., subFigure (b) of Figure 6 shows pumping work indicated efficiency which is pumping work divided by total fuel energy. Positive values represent a gain due to very high efficiency of applied boost group. Detailed description of such normalization procedure of energy fluxes can be found in [33] (Appendix section of that paper).

\subsection{INFLUENCE OF ENGINE POWER CONTROL MEANS}

Considered means of engine power control are described above in the Chapter 4.1. Optimized results for the case of $0 \%$ EGR and $0 \%$ blow-by are shown in Figure 6 . The difference among the variants in terms of BSFC (subFigure (a) of Figure 6) is small, however, it can be significant and can make a difference when engine is supposed to be run for many years. As expected, the most efficient variant is fict $H P \_V G T$ due to the fact that no thermodynamic loss, which is associated with the boost pressure control and it can be quantified by pumping work (c.f. subFigure (b) of Figure 6), is imposed to control HP turbine power. Hence, using VGT means to apply just the right HP turbine size in terms of mass flow to reach boost pressure level which is needed. The main reason for BSFC difference is usually pumping work (subFigure (b) of Figure 6) as high-pressure phase indicated efficiency is very similar for all considered variants. There is almost no difference in heat transfer and mechanical efficiency as well. It is the pumping loss which determines overall brake efficiency. It is interesting to note that the variants throttle and blow-by are very similar (both variants, i.e., throttle and blow-by, are very similar in terms of BSFC and pumping losses although the reasons are different - this similarity leads to the fact that both curves, i.e., dark blue for throttle and pink one for blow$-b y$, coincide) while they are the worst ones in terms of BSFC. Both waste-gate variants are between fict_HP_VGT and throttle in terms of BSFC while HP waste-gate (variant $W G_{-}$ HP_only) is slightly better than waste-gating both turbines (variant $W G$ ). This is obvious result as exhaust gases, which by-pass HP stage, can be expanded in LP turbine to use some of its internal energy. When using by-pass of both turbines, this is not possible and all the internal energy of by-passing exhaust gases is lost. However, the difference is small due to the fact that optimal turbochargers require only limited waste-gating. There are differences in maximal achievable power. However, this is a side-effect result and it follows expected trend that the variants with higher thermodynamic losses, which are associated with boost pressure control, can reach higher power levels as they have certain amount of a reserve boost pressure (c.f. Figure 8).
Concerning turbocharger performance, the following can be stated. There are relatively small differences of HP turbocharger efficiency which are related to pumping work while LP turbocharger operation is very similar for all variants. Since less efficient variants require higher boost pressure, HP turbocharger speed is higher as well. However, the difference in turbocharger speed and/or efficiency is also related to distribution of PR between HP and LP stage. It was to be expected that LP turbocharger would provide more compression/expansion work as it is more efficient and compressor inlet temperature is not increased (as it is the case for HP compressor due to upstream compression at LP stage). There are significant differences as variants

(a) brake specific fuel consumption (detail)

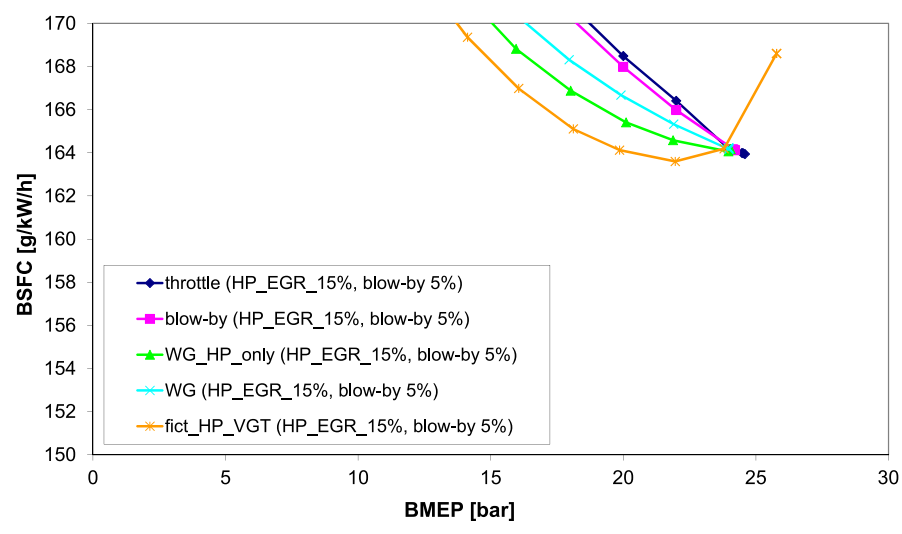

(b) pumping indicated efficiency

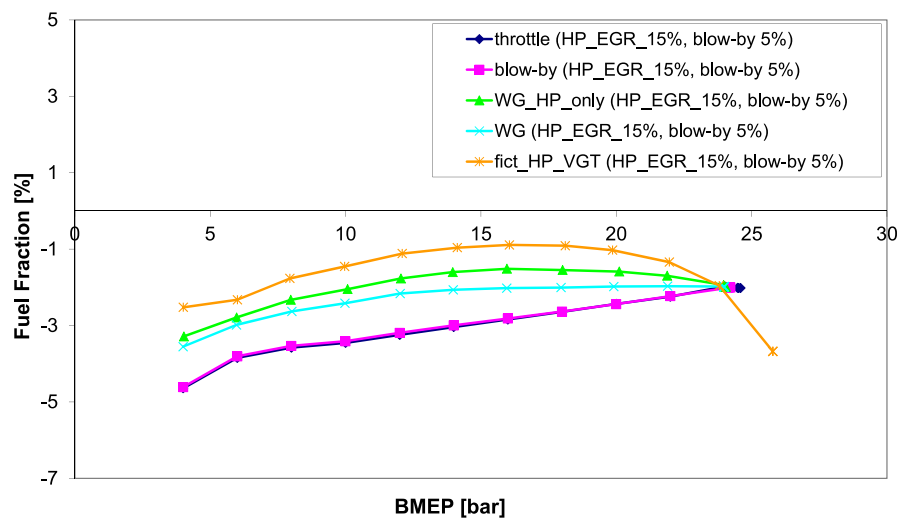

FIGURE 9: Comparison of different control means under steady operation - selected engine output parameters; engine setting: blow-by $=5 \%$, EGR $=0 \%$ (at BMEP $=24$ bar), TA Luft $=100 \%, H P E G R+$ EGR compressor.

OBRÁZEK 9: Srovnání různých způsobů řízení motoru za ustálených podmínek - vybrané výstupní parametry motoru; nastavení: blow-by = $5 \%, \mathrm{EGR}=0 \%$ (pro BMEP $=24$ bar), TA Luft $=100 \%$, varianta HP EGR + EGR compressor. 
fict_HP_VGT and WG_HP_only require more work form LP stage. Concerning compressor surge, it is typical that all variants operate very closely to the surge limit (c.f. Figure 8). The only exception is blow-by variant which is much safer in terms of possible surge due to a reason of compressor by-pass application which increases compressor mass flow rate at the same level of PR. The steep increase of most parameters of variant fict_HP_VGT for BMEP higher than 24 bar is caused by non-linearity of VGT control.

Similar trends can be observed when engine is operated under different conditions in terms of blow-by, EGR and/or air excess $\left(\mathrm{NO}_{x}\right.$ level) - c.f. Figures 7 and 9 . It is usually possible to find suitable turbocharger(s) in terms of their swallowing capacity (realistic mass flow limits of turbocharger(s) were considered as the turbocharger manufacturer provided the maps - these limits are related to design constraints) to provide just the needed boost pressure to achieve required BMEP level - this would lead to the fact that all the variants have the same BSFC at BMEP of 24 bar (c.f. Figure 7). However, such variant (with the exception of fict_HP_VGT one) has no boost pressure reserve, hence it would require long time to reach BMEP target, thus being unsuitable for fast engine load changes. The above described differences of BSFC in terms of different control means are magnified when an engine load is decreased, as a boost pressure control is unavoidable. Based on that, the conclusions have general relevance - the most efficient control is the VGT one while the least efficient ones are throttling and compressor blow-by.

\subsection{INFLUENCE OF EGR ROUTE CONFIGURATION}

Considered EGR variants are summarized above in the Chapter 4.2 and figure 5 . The results concerning comparison of all EGR variants are shown in Figure 10. It was expected that the variants with balanced flow (the term balanced flow means that mass flow rate through compressor is approximately equal to mass flow rate through turbine) will be better in terms of BSFC - these variants are LP EGR (this variant is usually labelled as $L P \_E G R$ in figures/legend) and HP EGR $+E G R$ compressor (this is the default EGR variant, hence no special label is used in figures - it is simply labelled as $E G R$ in Figure legend; the only exception is Figure 10, where it is explicitly labelled as HP EGR +EGR compressor). The difference between those 2 variants and the one without EGR (labelled as no_EGR in the figures) is relatively small, which is caused by low EGR requirement (7.5\%). The dominant phenomenon is pumping work. It is significantly worse for variants with non-balanced flow as the turbochargers are not optimized for such operation. Turbine is being overloaded by compressor when the flow is not balanced. The variant
HP EGR + EGR compressor is supposed to be equipped with electrically driven compressor. When dedicated EGR compressor is applied, it requires certain amount of power to pump exhaust gases back into intake system. This energy is supplied from engine crank train taking into account efficiency of electric motor (95\%). This energy is related to gas exchange, hence it needs to be considered when analyzing low pressure part of engine work cycle. Based on that, the sum of pumping work and attachment work is plotted in subFigure (b) of Figure 10. The former is related to pressure forces acting on piston during gas exchange, the latter concerns power requirements of dedicated EGR compressor. Hence, such graph (pumping work + attachment power) is shown whenever there is a variant with dedicated EGR compressor.

\section{(a) brake specific fuel consumption (detail)}

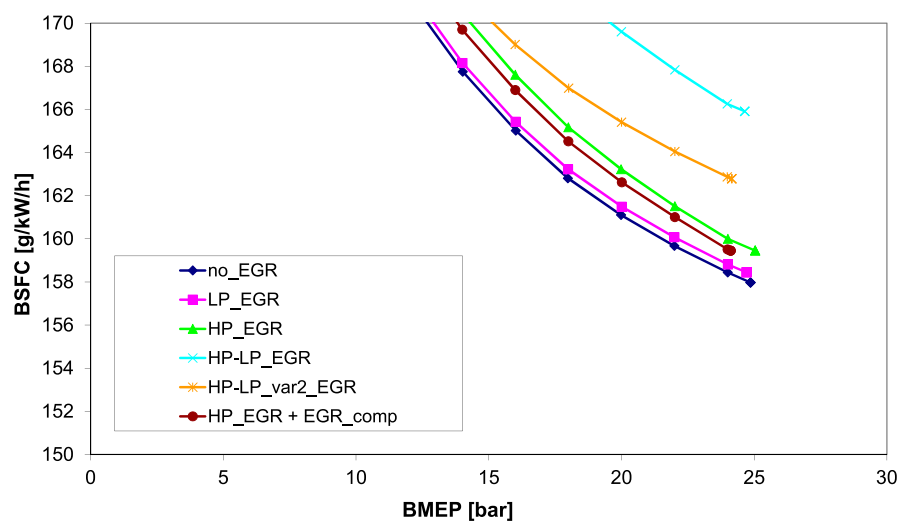

(b) pumping indicated efficiency + attachment power fuel fraction

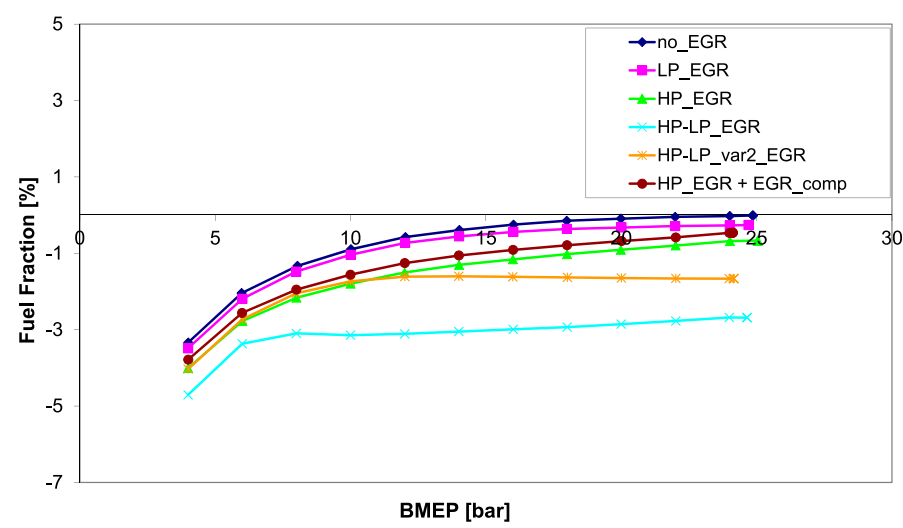

FIGURE 10: Comparison of different EGR variants under steady operation - selected engine output parameters; engine setting: blow-by $=0 \%, \mathrm{EGR}=7.5 \%$ (at BMEP $=24$ bar), prescribed air excess.

OBRÁZEK 10: Srovnání různých EGR variant za ustálených podmínek vybrané výstupní parametry motoru; nastavení: blow-by $=0 \%, E G R=7.5 \%$ (pro BMEP = 24 bar), předepsaný průběh prebytku vzduchu. 
(a) BSFC: req. $E G R=7 \%$ at BMEP $=24$ bar, TA Luft $=100 \%$

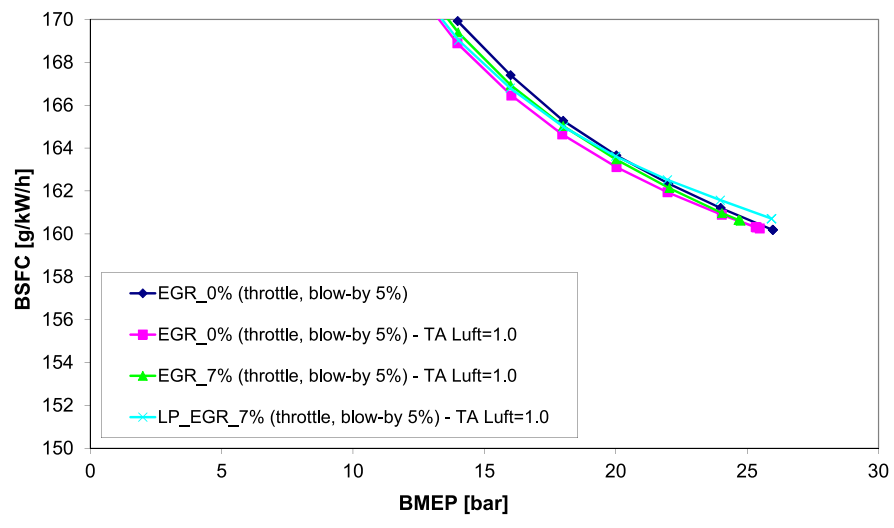

(c) BSFC: req. $E G R=7 \%$ at $B M E P=24$ bar, $T A$ Luft $=50 \%$

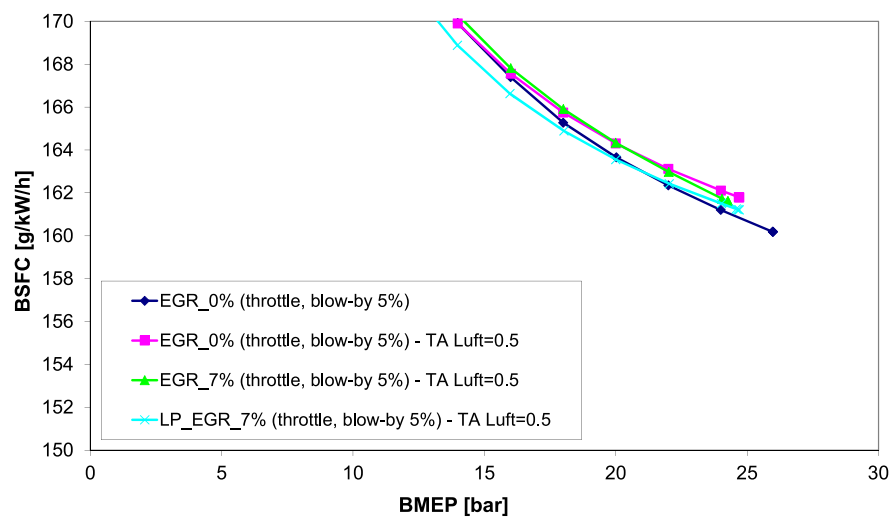

(e) BSFC: req. $E G R=7 \%$ at BMEP $=24$ bar, $T A$ Luft $=25 \%$

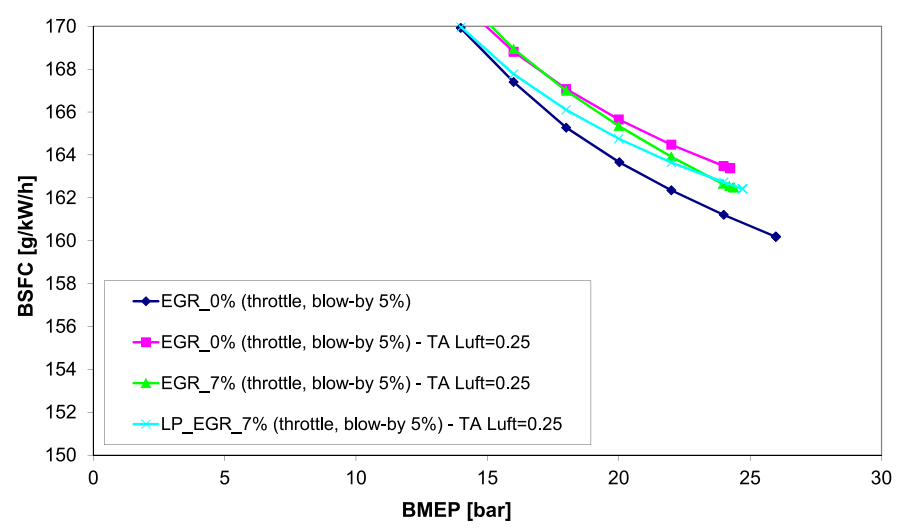

(b) BSFC: req. $E G R=23 \%$ at $B M E P=24$ bar, $T A$ Luft $=100 \%$

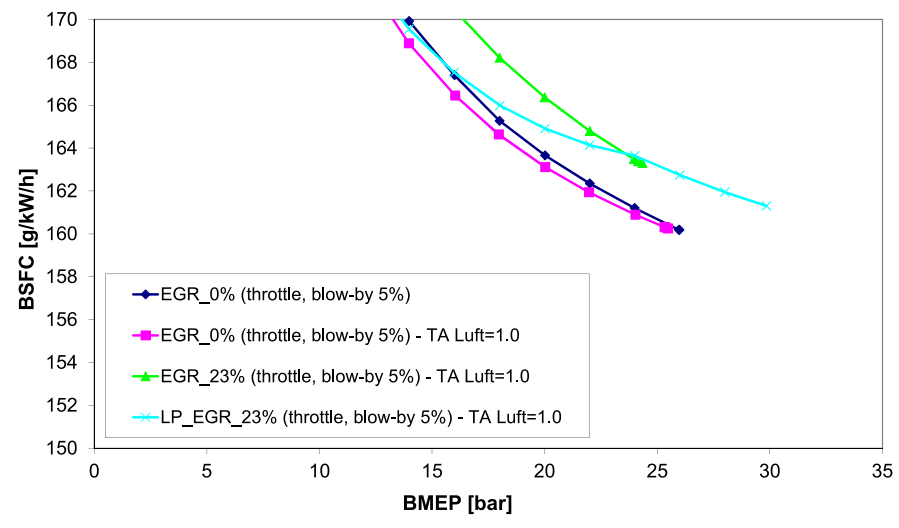

(d) BSFC: req. $E G R=23 \%$ at $B M E P=24$ bar, $T A$ Luft $=50 \%$

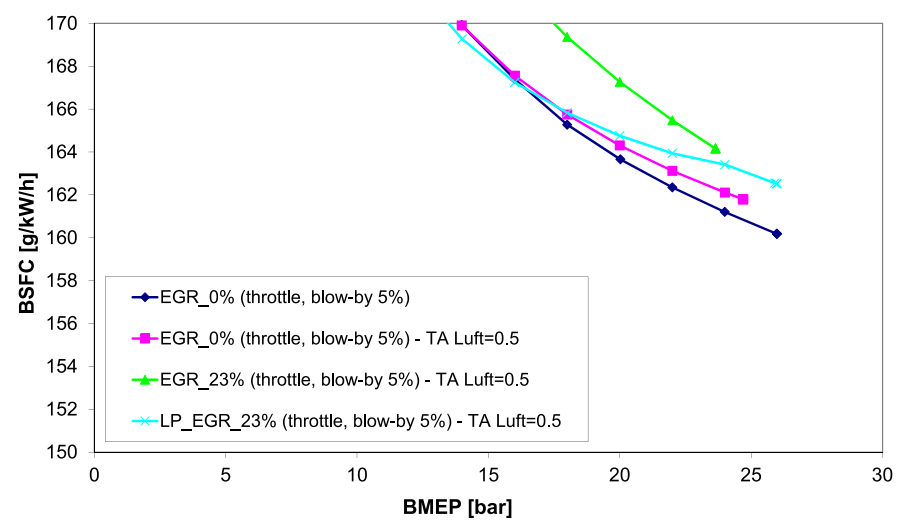

(f) BSFC: req. $E G R=23 \%$ at $B M E P=24$ bar, $T A$ Luft $=25 \%$

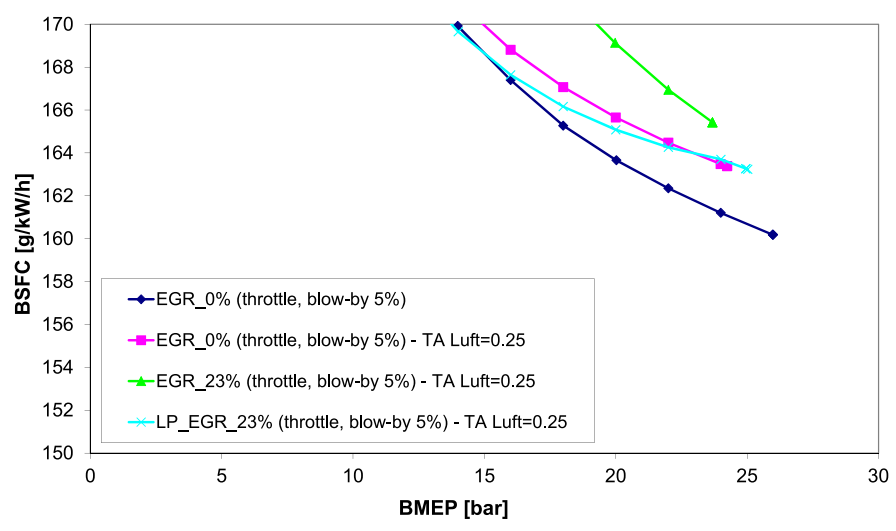

FIGURE 11: Comparison of different EGR configurations at different EGR and/or TA Luft levels under steady operation - selected engine output parameters; engine setting: blow-by $=5 \%$.

OBRÁZEK 11: Srovnání různých EGR konfigurací pro různé úrovně EGR a/nebo NOx (dle TA Luft) za ustálených podmínek - vybrané výstupní parametry motoru; nastavení: blow-by $=5 \%$. 
It is no surprise that $L P E G R$ is the best variant as it preserves balanced flow while taking advantage of existing pressure losses of exhaust pipe system located downstream of LP turbocharger. Comparison of HP EGR + EGR compressor variant with $L P E G R$ variant is also presented in Figure 11. This Figure is in-line with the above mentioned facts. Unlike in the previously mentioned cases, where both EGR level and air excess were prescribed, these data concern constant levels of $\mathrm{NO}_{\mathrm{x}}$ at different $\mathrm{EGR}$ levels. It seems that $L P E G R$ variant can satisfy all considered $\mathrm{NO}_{x}$ levels (based on TA Luft norm) without additional exhaust throttling, hence it is usually better than HP EGR + EGR compressor one. Moreover, as the mass flow increases due to requirement of higher BMEP, natural pressure loss is increased as well, hence $L P E G R$

(a) brake specific fuel consumption (detail)

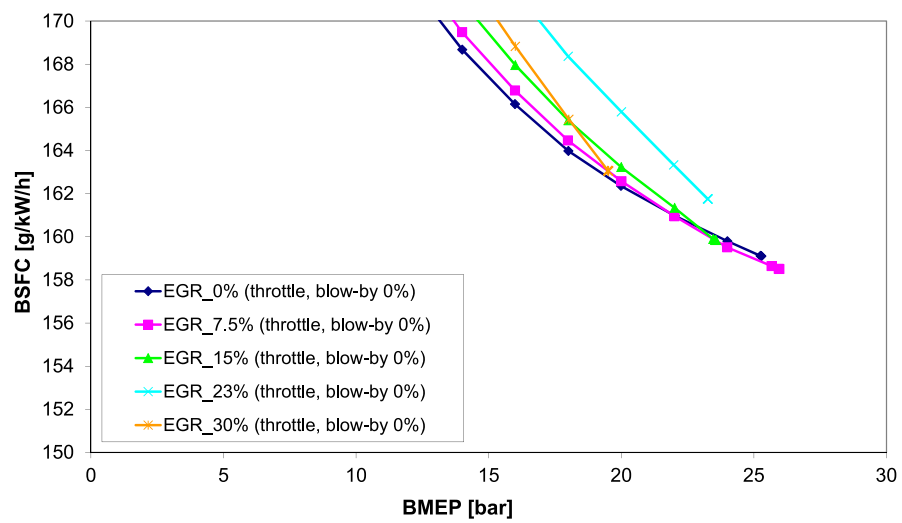

(b) pumping indicated efficiency + attachment power fuel fraction

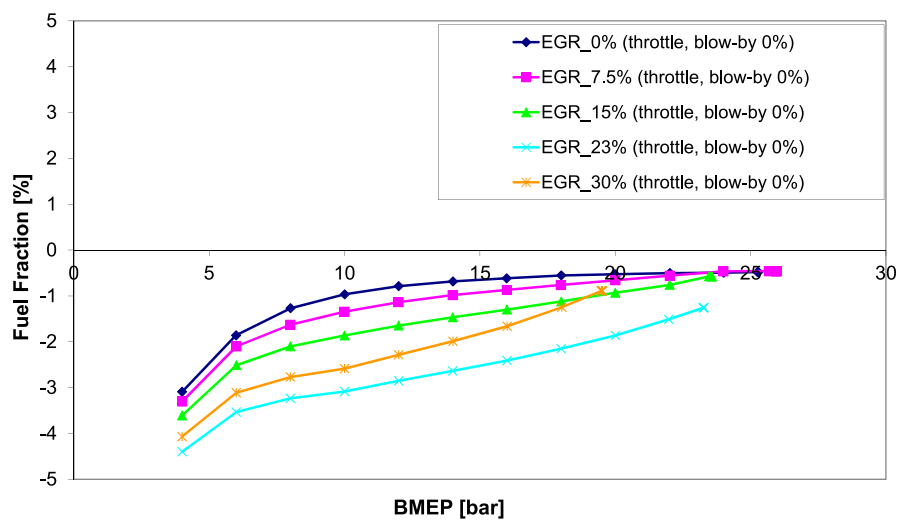

FIGURE 12: Comparison of different amounts of EGR under steady operation - selected engine output parameters; engine setting: blow-by $=0 \%$, prescribed air excess, HP EGR +EGR compressor.

OBRÁZEK 12: Srovnání různých množství EGR za ustálených podmínek

- vybrané výstupní parametry motoru; nastavení: blow-by $=0 \%$, předepsaný průběh přebytku vzduchu, varianta HP EGR + EGR compressor. variant can provide high EGR rate even at very high BMEP levels ( $\geq 24$ bar). On top of that, as the mass flow increases, $\mathrm{HP}$ turbine efficiency is increased as well (c.f. Figure 2) which improves both pumping work and maximum achievable power. Both effects are limited in the case of $H P E G R+$ EGR compressor application. The higher EGR requirement, the smaller positive effect of HP turbine efficiency increase. Hence, BSFC difference is increased for higher EGR levels making $L P E G R$ variant clearly a better one. On the other hand, the variant $L P E G R$ is negatively influenced by the fact that LP compressor inlet temperature is increased when non-zero EGR is required which increases compressor work. This effect gets stronger as EGR requirement increases, hence BSFC of LP EGR variant might be actually worse (when

(a) brake specific fuel consumption (detail)

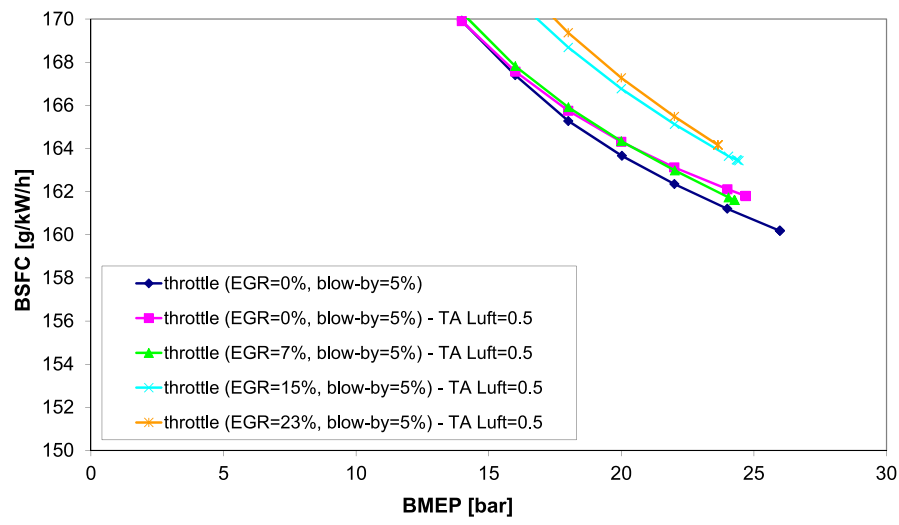

(b) pumping indicated efficiency + attachment power fuel fraction

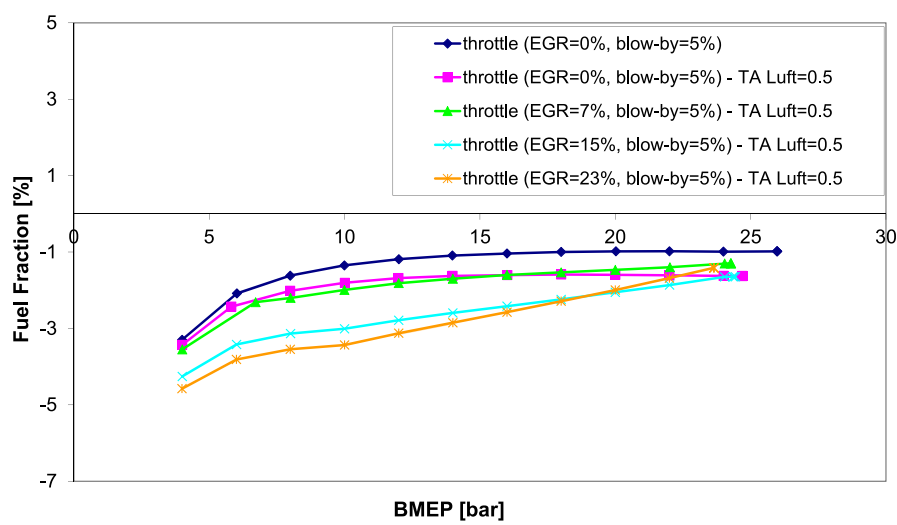

FIGURE 13: Comparison of different amount of EGR under steady operation - selected engine output parameters; engine setting: blow-by $=5 \%$, TA Luft $=50 \%$, HP EGR + EGR compressor .

OBRÁZEK 13: Srovnání různých množství EGR za ustálených podmínek vybrané výstupní parametry motoru; nastavení: blow-by $=5 \%$, TA Luft $=50 \%$, varianta $\mathrm{HP} E \mathrm{ER}+\mathrm{EGR}$ compressor. 
(a) brake specific fuel consumption (detail)

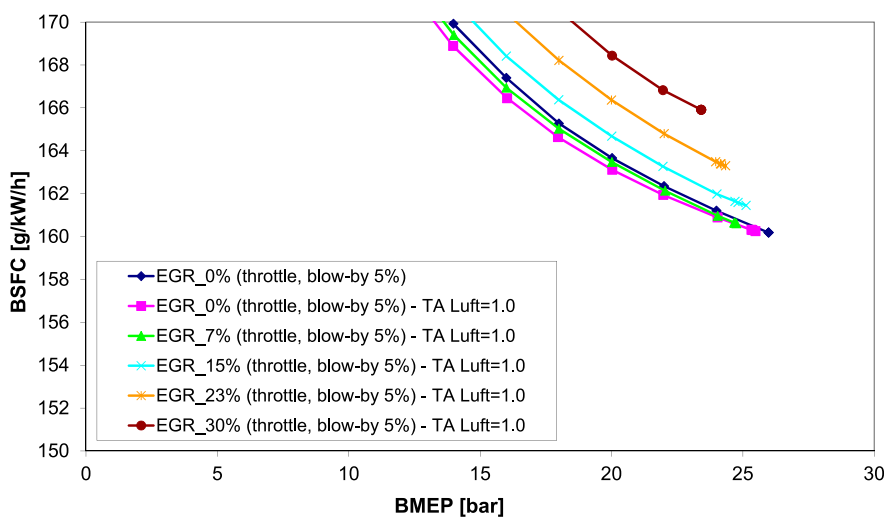

(c) indicated efficiency of HP phase

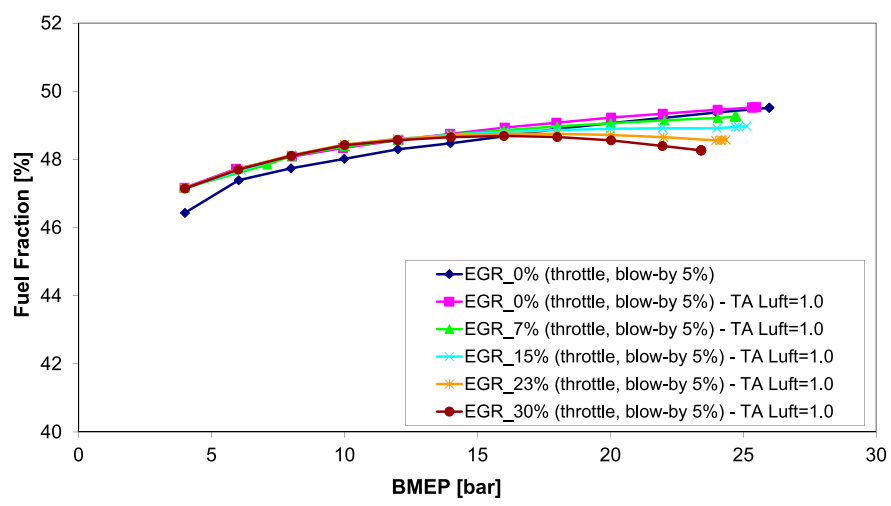

(e) air excess (based on free oxygen)

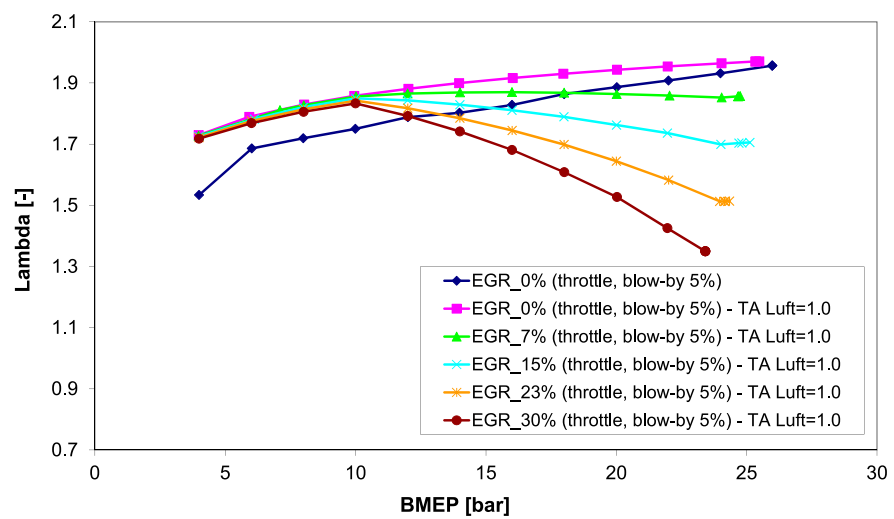

W(b) pumping indicated efficiency + attachment power fuel fraction

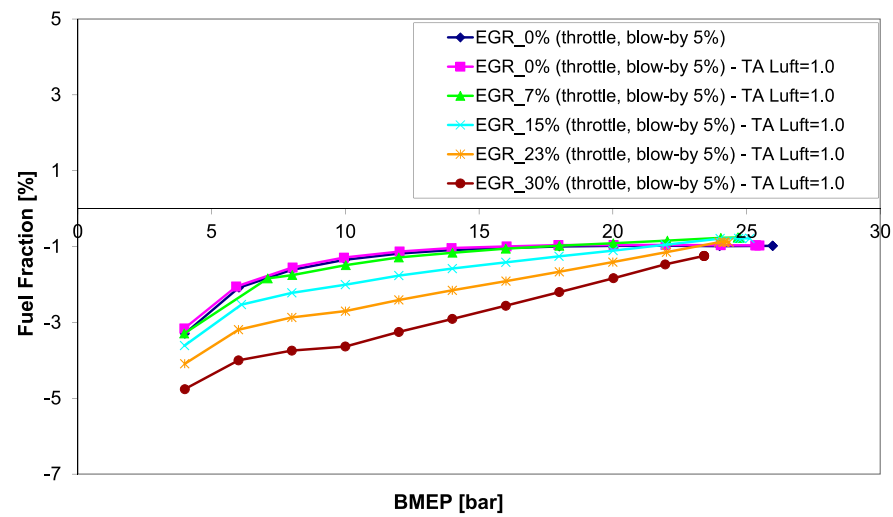

(d) in-cylinder heat transfer

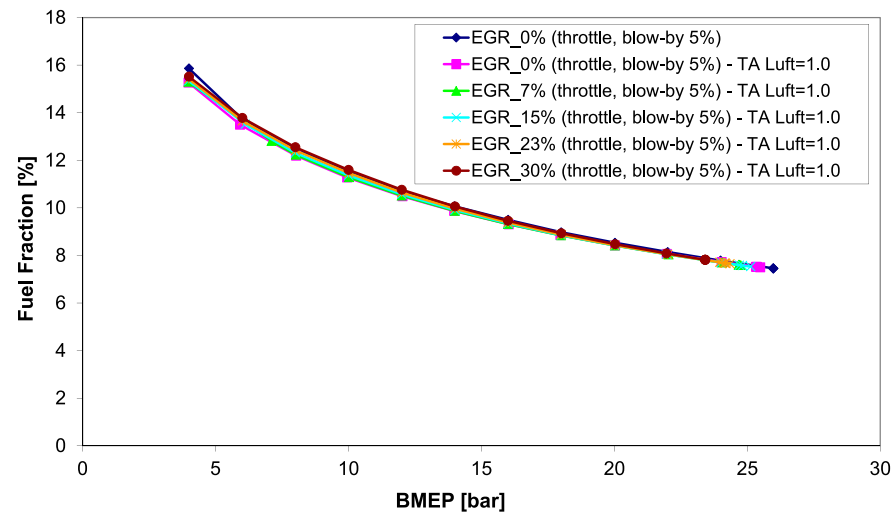

(f) total in-cylinder EGR (external + internal)

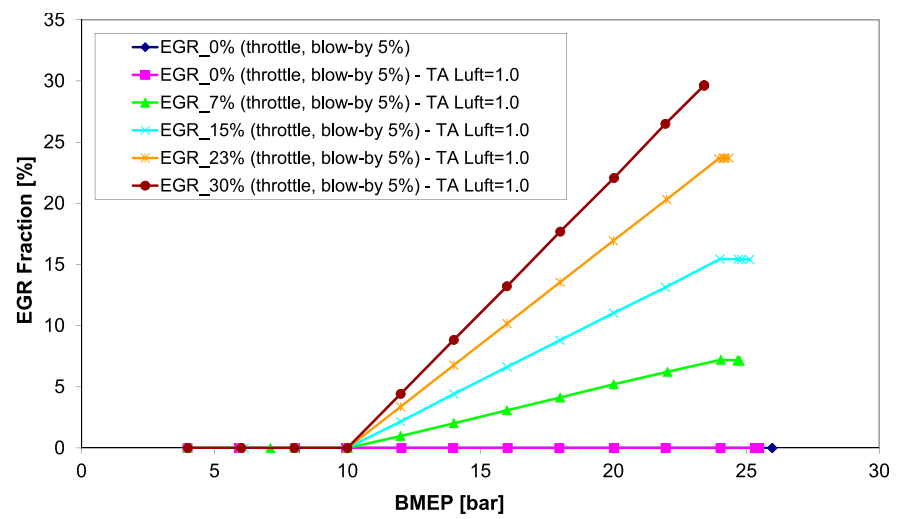

FIGURE 14: Comparison of different amounts of EGR under steady operation - selected engine output parameters; engine setting: blow-by $=5 \%$, TA Luft $=100 \%, H P E G R+$ EGR compressor.

OBRÁZEK 14: Srovnání různých množství EGR za ustálených podmínek - vybrané výstupní parametry motoru; nastavení: blow-by = 5\%, TA Luft $=100 \%$, varianta HP EGR + EGR compressor. 
compared with variant $H P E G R+E G R$ compressor) when very high EGR ( $30 \%$ ) is required. However, optimal values of EGR rate are in the range between 0 and $10 \%$ (c.f. Figure 17). These are low values and the above mentioned effects are relatively small under these conditions.

Based on above mentioned facts, it is expected that both EGR variants are the optimal solution for the target engine while each one has its own advantages and disadvantages. The main advantage of variant HP EGR + EGR compressor is the ability to provide almost any EGR requirement. Moreover, it has the shortest geometrical distance for EGR to get from cylinder through exhaust/EGR/intake piping back to cylinder. This is important advantage for transient cases. This enables to minimize transport delays of the system (c.f. [36]). However, large-bore engines are not yet supposed to satisfy pollutant limits under transient operation. The main advantages of variant $L P E G R$ are simple design and low BSFC penalty.

\subsection{INFLUENCE OF REQUIRED EGR LEVEL}

The amount of external EGR is an important factor. It determines engine efficiency and pollutant formation $\left(\mathrm{NO}_{\mathrm{x}}\right)$. The influence of required EGR level for the case of prescribed air excess is plotted in Figure 12. When EGR requirement is low (0-15\%), there is almost no difference in BSFC. Higher EGR rate leads to lower heat transfer losses, hence higher indicated efficiency of engine HP phase (of ICE thermodynamic cycle). Even pumping work is slightly improved due to higher LP stage efficiency and higher boost pressure. However, these positive effects are compensated by power requirement of EGR compressor. The overall effect is that BSFC is very similar at high BMEP level (near 24 bar of BMEP). When EGR requirement is increased, it is more difficult to get enough fresh air into cylinder(s). This

effect was already discussed above and it is related to the fact that the boost group is approaching its limit which causes that boost pressure is limited regardless of exhaust back pressure. This leads to increase of BSFC for higher EGR levels (23 and $30 \%$ ). Moreover, maximum achievable BMEP is significantly decreased (when EGR requirement is $30 \%$, BMEP target of 24 bar cannot be reached). From thermodynamic point of view, there is an optimum value of EGR for given air excess.

However, the level of $\mathrm{NO}_{x}$ was not considered in the case, which was discussed in the paragraph above. It is obvious that higher EGR level in combination with the same air excess will clearly lead to lower $\mathrm{NO}_{\mathrm{x}}$ formation. As the chemical kinetics, which controls $\mathrm{NO}_{x}$ formation, is driven by exponential dependency on temperature, the influence of in-cylinder temperature on $\mathrm{NO}_{x}$ is strongly non-linear. This effect is supposed to be properly captured by applied multi-zone $\mathrm{NO}_{x}$ model. The comparison of different EGR level cases while $\mathrm{NO}_{\mathrm{x}}$ level is constant (TA Luft at level of 100\%) is shown in Figure 14. From qualitative point of view, the results are the same as for the case of prescribed air excess. The main difference is in air excess and the fact that BSFC increase is already visible for EGR level of $15 \%$. Moreover, BSFC differences are larger due to missing effect of reduced heat transfer, which is visible for the case of prescribed air excess. Hence, the decisive factors are pumping work, which is closely related to the effect of increased HP stage efficiency when mass flow rate is high (more details can be found in Chapter 3.1), attachment work and mixture composition, which influences indicated efficiency of engine HP phase. The effect of mixture composition might be relatively significant as effective mixture LHV and Poisson constant (ratio of specific heat capacity at constant pressure over the capacity at constant specific volume) can change significantly while EGR requirement is varied. This influences in-cylinder pressure pattern which controls piston work. In the case of high EGR rate, Poisson constant is too low, hence pressure increase (due to energy release caused by combustion) is lower when compared with case of low EGR requirement. Concerning heat transfer, there is almost no difference among the variants of different EGR levels. Based on these facts, there is an optimal value of EGR rate in terms of BSFC, which is mainly driven by pumping work and efficiency of engine HP phase.

From qualitative point of view, similar trends can be observed for both optimal EGR variants ( $L P E G R$ and HP EGR + EGR compressor) while requiring more strict $\mathrm{NO}_{x}$ limits (at $50 \%$ or even $25 \%$ of TA Luft norm). The influence of required $\mathrm{NO}_{x}$ level is discussed bellow in Chapter 5.4.

\subsection{INFLUENCE OF REQUIRED N $0_{x}$ LEVEL}

The requirement of $\mathrm{NO}_{x}$ level is related to the level of TA Luft norm. Hence, $100 \%$ of TA Luft means that $\mathrm{NO}_{\mathrm{x}}$ is just at the limit defined by the norm $\left(500 \mathrm{mg}\right.$ of $\mathrm{NO}_{\mathrm{x}}$ per cubic meter, recalculated to the level of $5 \%$ free oxygen in exhaust gas). The results concerning that $(100 \%$ of $T A$ Luft $)$ are shown in Figure 14. If the limit is set to $50 \%$ of TA Luft, which is more demanding as the limit is only $50 \%$ of original TA Luft value, the results are plotted in Figure 13. Finally, even more strict requirement of $25 \%$ of TA Luft is shown in Figure 15. All these results are plotted in such a way that the lines of different EGR levels are shown. The main reason was to stress that the each requirement of $\mathrm{NO}_{\mathrm{x}}$ has its own optimal value of EGR level, which determines fresh air requirement. To get a better idea of the influence of more strict $\mathrm{NO}_{x}$ limit, Figure 16 was created. 
(a) brake specific fuel consumption (detail)

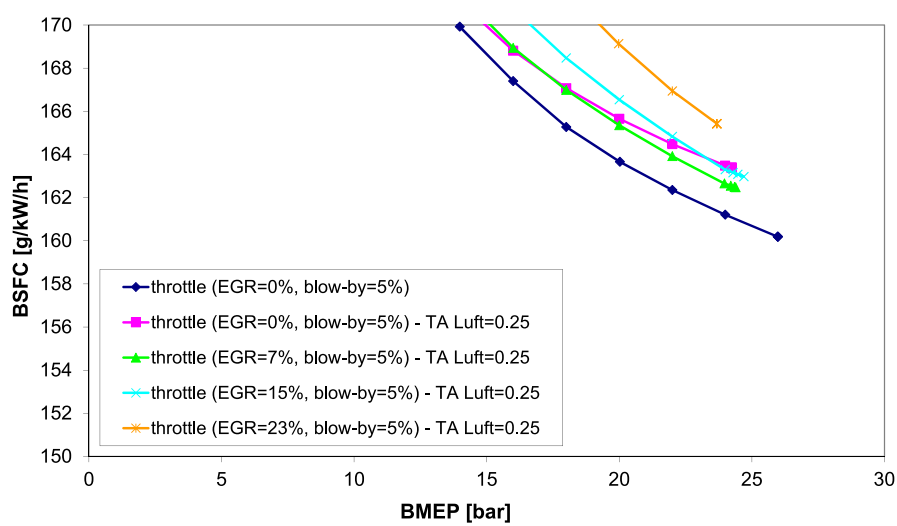

(b) pumping indicated efficiency + attachment power fuel fraction

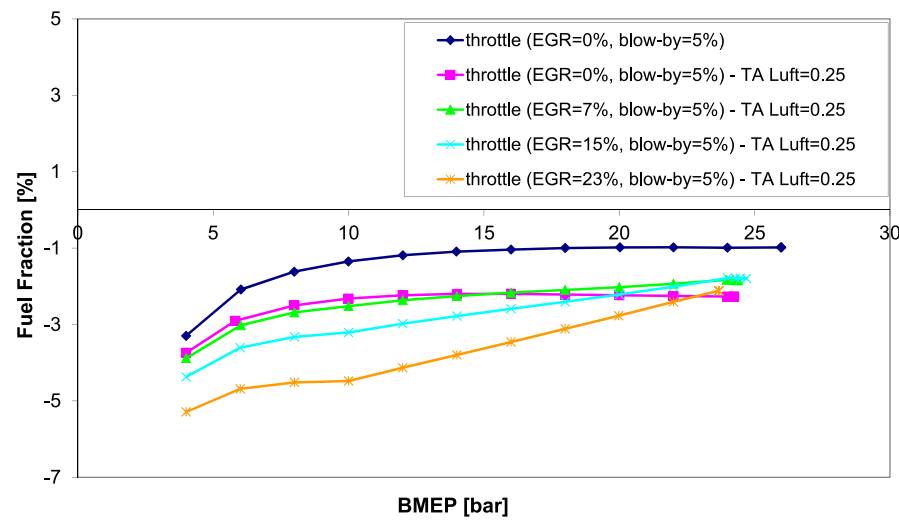

FIGURE 15: Comparison of different amount of EGR under steady operation - selected engine output parameters; engine setting: blow-by = 5\%, TA Luft $=25 \%$, HP EGR + EGR compressor.

OBRÁZEK 15: Srovnání různých množství EGR za ustálených podmínek - vybrané výstupní parametry motoru; nastavení: blow-by = 5\%, TA Luft = 25\%, varianta HP EGR + EGR compressor.

(a) $B S F C$ : required $E G R=0 \%$ at $B M E P=24$ bar

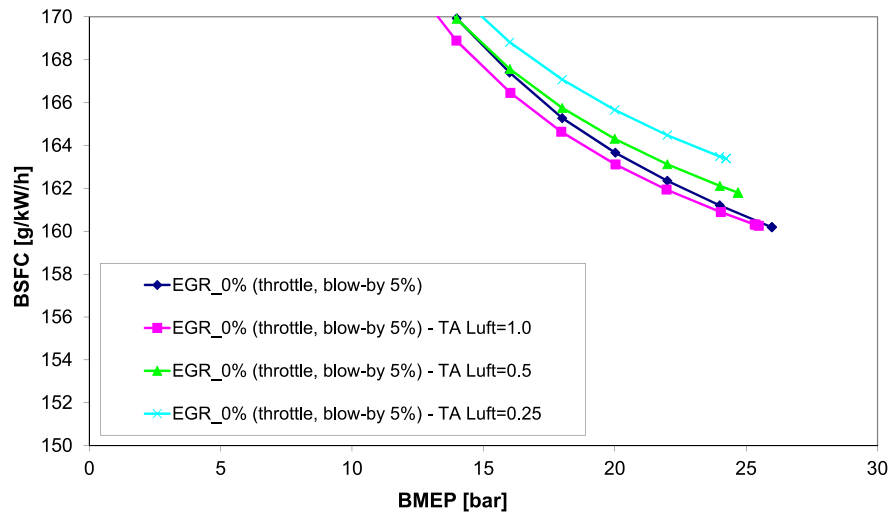

(c) $B S F C$ : required $E G R=15 \%$ at $B M E P=24$ bar

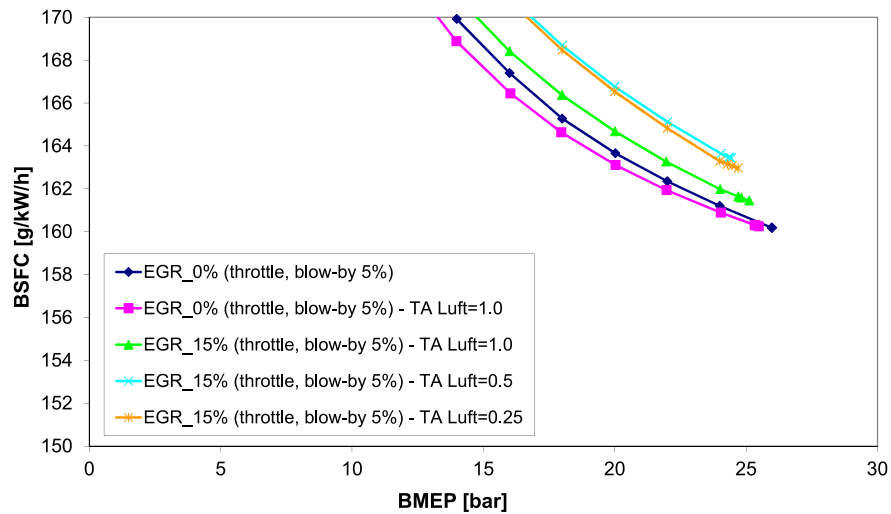

(b) $B S F C$ : required $E G R=7 \%$ at $B M E P=24$ bar

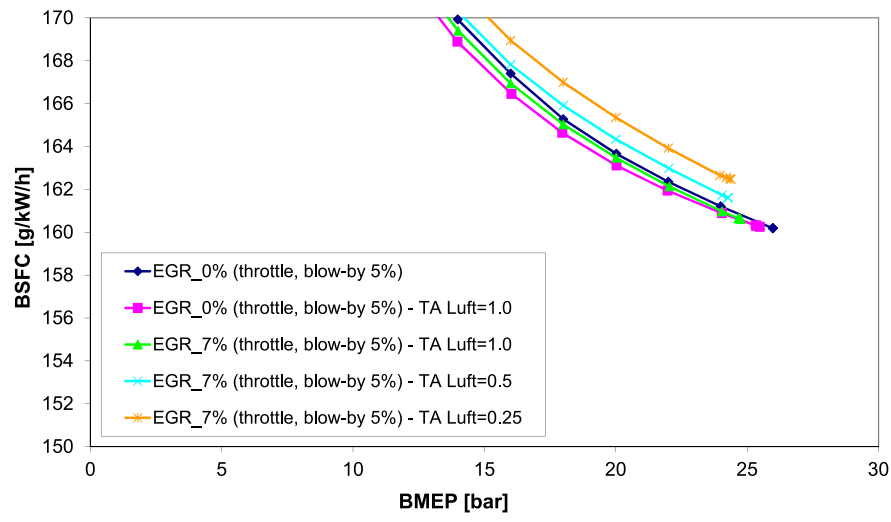

(d) $B S F C$ : required $E G R=23 \%$ at $B M E P=24$ bar

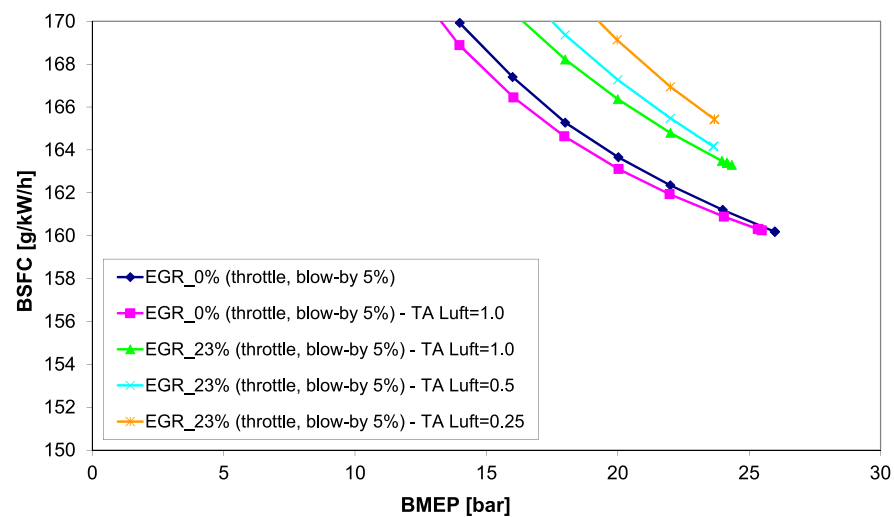

FIGURE 16: Comparison of different NOx levels (based on TA Luft norm) at different EGR levels under steady operation - selected engine output parameters; engine setting: blow-by $=5 \%, H P E G R+$ EGR compressor.

OBRÁZEK 16: Srovnání různých úrovní NOx (dle normy TA Luft) za ustálených podmínek - vybrané výstupní parametry motoru; nastavení: blow-by $=5 \%$, varianta $\mathrm{HP}$ EGR + EGR compressor. 
(a) brake specific fuel consumption (detail)

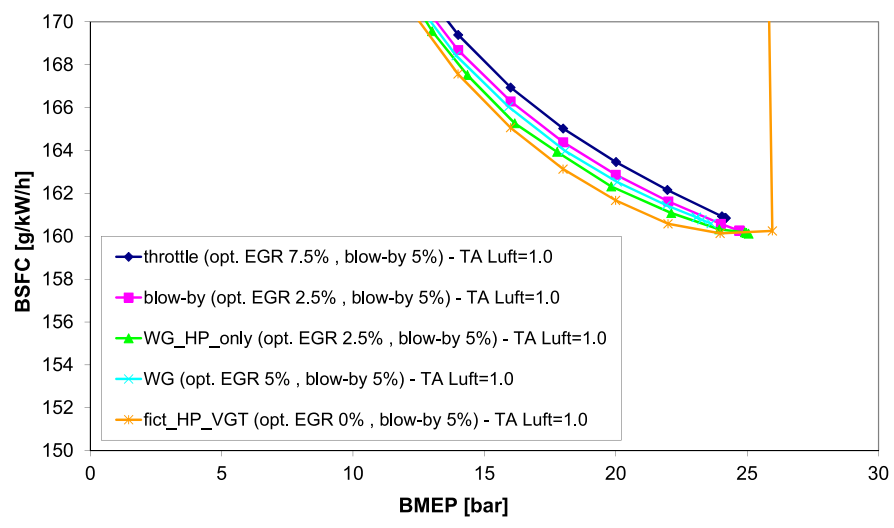

(c) pumping indicated efficiency + attachment power fuel fraction

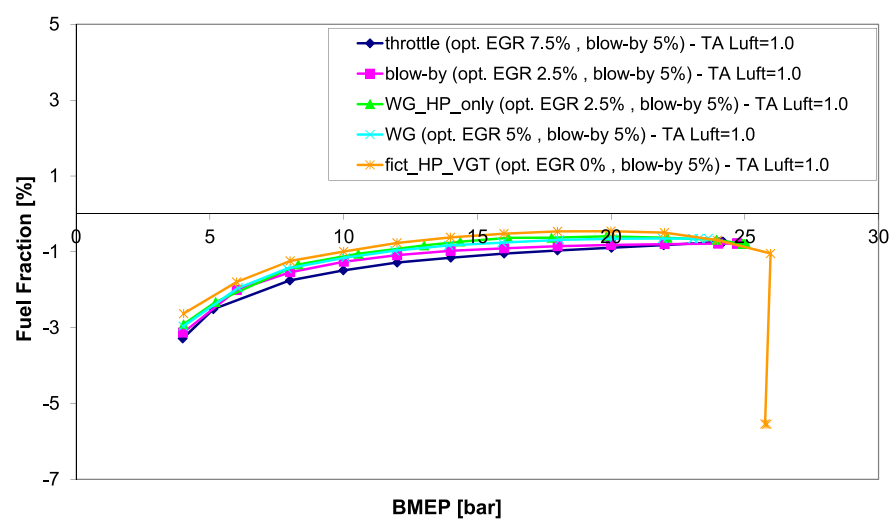

(e) total in-cylinder EGR (external + internal)

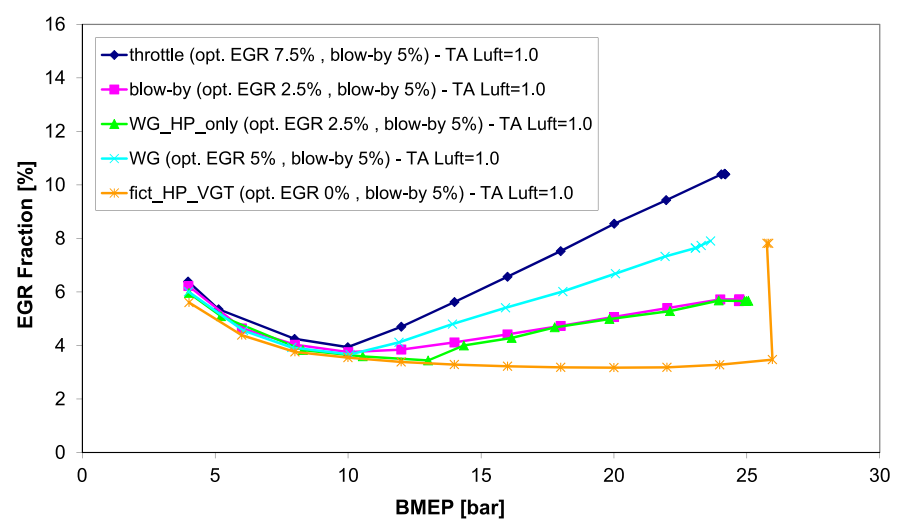

(b) brake specific fuel consumption (detail)

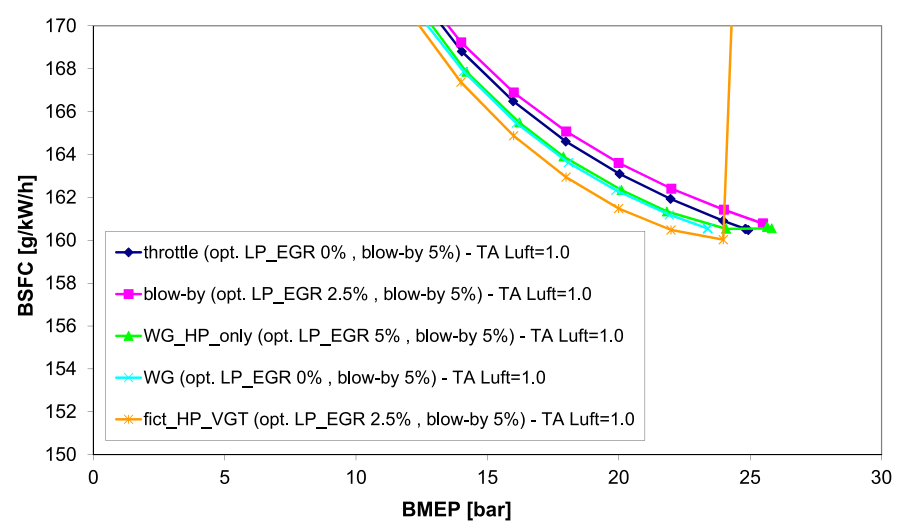

(d) pumping indicated efficiency + attachment power fuel fraction

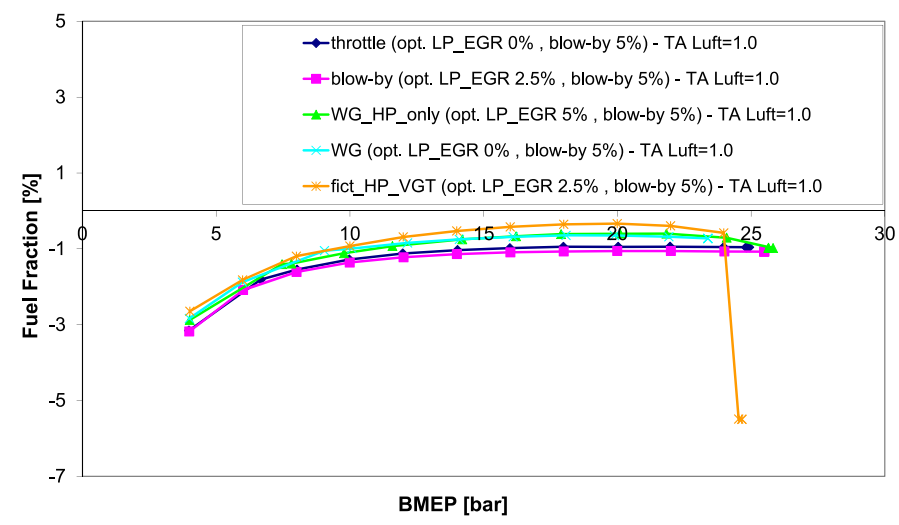

(f) total in-cylinder EGR (external + internal)

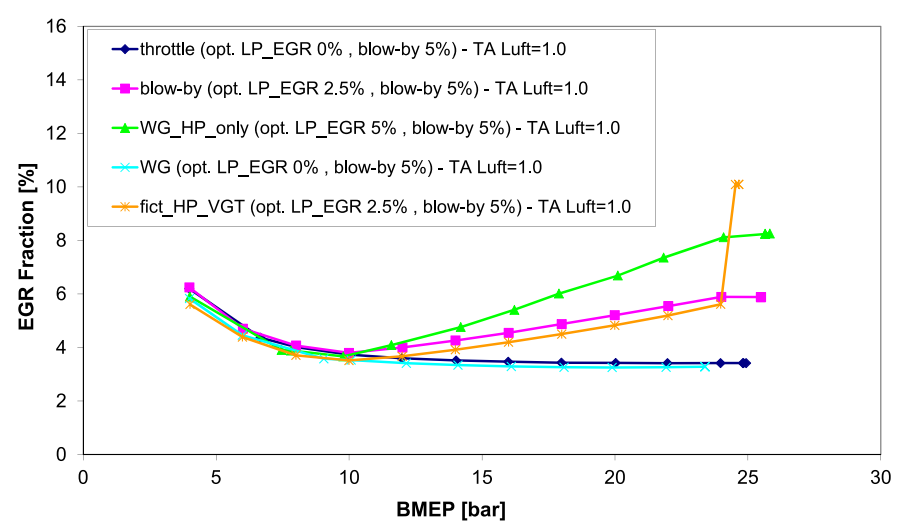

FIGURE 17: Comparison of different control means under steady operation - selected engine output parameters; engine setting: blow-by = 5\%, TA Luft $=100 \%, E G R=$ optimal, HP EGR + EGR compressor (left column) and LP EGR (right column).

OBRÁZEK 17: Srovnání různých způsobů rízení motoru za ustálených podmínek - vybrané výstupní parametry motoru; nastavení: blow-by = 5\%, TA Luft $=100 \%$, EGR = optimální, varianta HP EGR + EGR compressor (levý sloupec) a LP EGR (pravý sloupec). 
The subFigure (a) of Figure 16 presents the comparison of all considered variants at external EGR of $0 \%$. For the sake of comparison with other variants, 2 curves of $0 \%$ EGR are shown as well - the dark-blue one corresponds to calibrated engine model while pink one was optimized under 100\% TA Luft requirement. However, there is little difference between those 2 curves in terms of BSFC. Similarly, subFigure (b), subFigure (c) and subFigure (d) corresponds to 7, 15 and $23 \%$ of EGR respectively. As expected, more strict requirement leads to higher BSFC as more EGR and/or fresh air is needed to decrease in-cylinder temperature during combustion, hence limiting $\mathrm{NO}_{\mathrm{x}}$ formation. It seems that the BSFC penalty is not too high, especially for he case of $7 \%$ EGR.

The optimal values of EGR are shown in Figure 17, which concerns the case of $\mathrm{NO}_{\mathrm{x}}$ level at $100 \%$ of TA Luft and different control means. The optimal EGR values are relatively low (typically $5 \%$ ). Similar trends are observed for lower $\mathrm{NO}_{\mathrm{x}}$ levels. If $T A$ Luft at $50 \%$ is considered, optimal EGR rate varies between $7-10 \%$. If TA Luft at $25 \%$ is evaluated, optimal EGR requirement is between 10 and $15 \%$. As expected, lower $\mathrm{NO}_{x}$ levels require higher EGR rate, which is also confirmed by Figure 16. When comparing EGR variants ( $L P E G R$ versus $H P E G R+E G R$ compressor), the latter requires slightly higher EGR values. It seems that optimal value of EGR is not higher than $20 \%$ even for the case of very low $\mathrm{NO}_{x}$ level ( $\mathrm{TA}$ Luft at $12 \%)$. The decisive factor is pumping work which is closely related to the requirement of fresh air. The more strict $\mathrm{NO}_{x}$ limit, the higher air excess. It seems that the best compromise is to use relatively low amount of external EGR in combination with air excess in the range between 1.9 and 2.1. This is related to boost pressure potential of applied boost group, which cannot get much higher due to limits of applied turbochargers, and non-linearity of the whole problem in terms of in-cylinder temperature $\left(\mathrm{NO}_{\mathrm{x}}\right.$ level, heat transfer) and pumping work.

\section{CONCLUSIONS}

The paper summarizes the results of thermodynamic system simulations of 2-stage turbocharged large-bore lean-burn gas SI engine. The results concern steady state operation of the engine at constant speed. The main goal was to evaluate the potential of 2-stage turbocharging concept in terms of possible future applications, which will require more stringent emission $\left(\mathrm{NO}_{\mathrm{x}}\right)$ level. This means that sensitivity studies of selected parameters were performed while optimizing boost group configuration in terms of swallowing capacity of HP/LP compressor/turbine. That enables to find an optimal engine concept in terms of mixture quality, EGR circuit configuration and engine control while considering different $\mathrm{NO}_{\mathrm{x}}$ levels.
Concerning engine control, the following can be stated. HP stage VGT is the best variant in terms of overall efficiency (BSFC). Classical approach, which is the application of throttle located downstream of HP intercooler, is the worst one. Similar efficiency level can be achieved when engine power is controlled by means of compressor blow-by. Waste-gating is better than throttle control, however, it is worse than VGT one. The differences are not huge, however, they cannot be neglected. The dominant factor is pumping work. As the boost group approaches its limit in terms of maximum achievable boost pressure, which is basically driven by requirement of air excess or/and external EGR, the differences among the variants become smaller at BMEP of 24 bar.

Dealing with optimal configuration of EGR circuit, the variants $H P E G R+E G R$ compressor and LP EGR are the best ones. Both of them keep balanced flow through turbochargers. This means that compressor mass flow is almost the same as turbine one. This is very important as the turbochargers are designed in that way. When using other options (variants HP EGR, HP-LP EGR, HP-LP var. 2 EGR), this assumption is not satisfied which leads to significantly worse pumping work, hence worse BSFC. When comparing the best EGR variants, there is little difference between them when EGR requirement is low (up to $10 \%$ ) as negative effects, which are related to application of external EGR, are relatively low. However, when EGR rate is increased, $L P E G R$ becomes slightly better. If the requirement of EGR is too high, the pressure difference between exhaust system and intake one is not sufficient and the only way to satisfy EGR requirement is to apply exhaust throttling which leads to exhaust back pressure increase, hence BSFC increase. The final selection of EGR variants is not a clear cut. Under certain operating conditions, $L P E G R$ variant is better while $H P E G R+E G R$ compressor one is more convenient in all other cases. It should be stressed that the variant $H P E G R$ + EGR compressor requires dedicated EGR compressor, the speed of which is supposed to be controlled by electric motor. This increases cost and control complexity.

Regarding the influence of required $\mathrm{NO}_{x}$ level, the dependency is obvious - the more strict requirement, the higher BSFC. Moreover, each $\mathrm{NO}_{x}$ level has its own optimal combination of EGR and air excess. To satisfy TA Luft of $100 \%$, it seems that no external EGR is needed as optimal EGR rate is low, which is typically $2.5-5 \%$ depending on applied BMEP control. When TA Luft of $50 \%$ is required, EGR level about $7-10 \%$ is the optimal value while at TA Luft of $25 \%$, EGR level between 10 and $15 \%$ is expected to be the best choice. Simulation results also suggest that significant lowering of a $\mathrm{NO}_{x}$ limit leads to relatively low BSFC penalty. This is caused by non-linearity effects and by the fact that HP turbine efficiency increases when mass flow is increased. Based on these facts, the optimal strategy seems to 
be a combination of relatively low external EGR with relatively high air excess. That is enabled by high efficiency 2-stage boost group which is able to provide very high boost pressure. This is needed to achieve both low $\mathrm{NO}_{\mathrm{x}}$ level and high thermodynamic efficiency due to application of Miller cycle.

When evaluating the potential of 2-stage turbocharging approach for the case of large-bore lean-burn gas $\mathrm{SI}$ engine, the following can be stated. It can provide very high boost pressure, hence extreme cases of required EGR and/or $\mathrm{NO}_{x}$ level can be satisfied while meeting high BMEP requirement. Moreover, strong Miller cycle (early IVC) was applied in all tested cases, which increases requirement of boost pressure even more. Although the efficiency of applied 2-stage boost group is relatively high as the considered turbochargers have state-of-the-art performance parameters, it has its limits. Once these limits are approached, engine BSFC starts to increase significantly. This negative phenomenon has to be avoided. This can be achieved by careful optimization of the whole engine. Not only turbochargers, but other important parameters should be taken into account as well including EGR configuration, engine compression ratio, intake/exhaust valve timing, etc. This was not done - the paper primarily focuses on optimization of boost group while evaluating different concepts in terms of EGR level, EGR circuit configuration, engine control and $\mathrm{NO}_{x}$ level. Concerning boost pressure control, it is definitely more demanding when compared with single-stage boost group. Especially the variants, which change pressure distribution between stages (i.e., fict_HP_VGT and WG_HP_only), can be tricky in terms of stable BMEP control.

Final comment concerns optimal size of applied compressor/ turbine of each turbocharger. Regarding compressors (both HP and LP stage), the optimal size is very similar for all considered variants regardless of BMEP control, EGR route configuration or $\mathrm{NO}_{x}$ level. This is not a surprise as the engine geometry parameters are fixed. This mainly concerns valve timing (especially IVC). Dealing with HP turbine, its optimal size changes relatively strongly. When $\mathrm{NO}_{\mathrm{x}}$ level is decreased, HP turbine size is decreased as well and it is always slightly smaller for the EGR variant HP EGR + EGR compressor. This statement is also predictable as lower $\mathrm{NO}_{\mathrm{x}}$ requires higher boost pressure. When comparing both EGR variants, it is obvious that HP EGR + EGR compressor variant needs smaller HP turbine as its mass flow rate is smaller due to EGR. Optimal LP turbine size varies only slightly - typically it is within $10 \%$. Moreover, it was verified that its influence on BSFC is very low, hence the same turbine can be applied to all optimal cases without any significant BSFC penalty. It also follows expected trend that slightly larger LP turbine is needed for the variant $L P E G R$. Based on all available facts, the most dominant factor is HP turbine size.

\section{REFERENCES}

[1] GT-Power User's Manual, GT-Suite version 7.3. Gamma Technologies Inc., 2012.

[2] modeFRONTIER - Multi-Objective Design Environment, version 4.4.3. [CD-ROM], 2012.

[3] Behr, T., Kahi, M., Reichl, A., and Hubacher, M. Second Generation of Two-stage Turbocharging Power2 Systems for Medium Speed Gas and Diesel Engines. Proceedings: Conseil International Des Machines A Combustion (CIMAC) Congress 2013, Shanghai, May 2013. Paper No.: 134.

[4] Bogomolov, S., Doleček, V., Macek, J., Mikulec, A., and Vítek, O. Combining Thermodynamics and Design Optimization for Finding ICE Downsizing Limits. SAE Technical Paper Series, April 2014. Paper 2014-01-1098, doi: 10.4271/2014-01-1098.

[5] Bozung, H. G. Zweistufige Aufladeaggregate Wirkungsgrade und Gefälleaufteilung im Hinblick auf Vollastund Teillastbetrieb. MTZ, 39(5):209-215, 1978.

[6] Bozung, H. G. Die M.A.N.-Turboladerbaureihe NA und NA-VP für ein- und zweistufige Aufladung. MTZ, 41(4): 125-133, 1980.

[7] Chen, S. and Flynn, P. Development of a Single Cylinder Compression Ignition Research Engine. SAE Technical Paper Series. Paper 650733, doi: 10.4271/650733.

[8] Christen, C. and Brand, D. IMO Tier 3: Gas and Dual Fuel Engines as a Clean and Efficient Solution. Proceedings: Conseil International Des Machines A Combustion (CIMAC) Congress 2013, Shanghai, May 2013. Paper No.: 187.

[9] Fiedler, M., Fiedler, H., and Boy, P. Experimental Experience Gained with a Long-Stroke Medium-Speed Diesel Research Engine using Two Stage Turbo Charging and Extreme Miller Cycle. Proceedings: Conseil International Des Machines A Combustion (CIMAC) Congress 2013, Shanghai, May 2013. Paper No.: 253.

[10]Izumi, S. and Hirayama, Y. Two-Stage Turbocharged MITSUBISHI UE-E Type Diesel Engine. Journal of the Japan Society of Mechanical Engineers, 79(694):864869, 1976.

[11]Kesgin, U. Effect of Turbocharging System on the Performance of a Natural Gas Engine. Energy Conversion and Management, Vol. 46(1):11-32, January 2005. ISSN 01968904, doi: 10.1016/j.enconman.2004.02.006.

[12] Kesgin, U. Efficiency Improvement and NOx Emission Reduction Potentials of Two-Stage Turbocharged Miller Cycle for Stationary Natural Gas Engines. International Journal of Energy Research, Vol. 29(3):189-216, March 2005. ISSN 0363907X, doi: 10.1002/er.1048. 
[13] Lowe, A. and Morel, T. A New Generation of Tools for Accurate Thermo-Mechanical Finite Element Analyses of Engine Components. SAE Technical Paper Series, March 1992. Paper 920681, doi: 10.4271/920681.

[14]Macek, J., Vávra, J., and Vítek, 0. 1-D Model of Radial Turbocharger Turbine Calibrated by Experiments. SAE Technical Paper Series, March 2002. Paper 2002-01-0377, doi: 10.4271/2002-01-0377.

[15]Macek, J. and Vítek, 0. Contribution to Thermodynamic Design of Highly Turbocharged Engines. In: KoKa 2007, Bratislava, SR [CD-ROM], 2007.

[16]Macek, J. and Vítek, O. Simulation of Pulsating Flow Unsteady Operation of a Turbocharger Radial Turbine. SAE Technical Paper Series, April 2008. Paper 2008-01-0295, doi: 10.4271/2008-01-0295.

[17]Macek, J., Vítek, O., Burič, J., and Doleček, V. Comparison of Lumped and Unsteady 1-D Models for Simulation of a Radial Turbine. SAE Technical Paper Series, April 2009. Paper 2009-01-0303, doi: 10.4271/2009-01-0303.

[18]Macek, J., Vítek, O., and Žák, Z. Calibration and Results of a Radial Turbine 1-D Model with Distributed Parameters. SAE Technical Paper Series, April 2011. Paper 2011-01-1146, doi: 10.4271/2011-01-1146.

[19]Millo, F., Bernardi, M. G., and Delneri, D. Computational Analysis of Internal and External EGR Strategies Combined with Miller Cycle Concept for a Two Stage Turbocharged Medium Speed Marine Diesel Engine. SAE International Journal of Engines, Vol. 4(1):1319-1330, 2011. Paper 2011-01-1142, doi: 10.4271/2011-01-1142.

[20]Morel, T., Rackmil, C., Keribar, R., and Jennings, M. Model for Heat Transfer and Combustion in Spark Ignited Engines and its Comparison with Experiments. SAE Technical Paper Series, March 1988. Paper 880198, doi: $10.4271 / 880198$.

[21]Škarohlíd, M. Modelling of Influence of Biogas Fuel Composition on Parameters of Automotive Engines. In: Modeling of SI and Diesel Engines, April 2010. ISBN 978-0-7680-3418-9.

[22]Škarohlíd, $\mathrm{M}$. The Positive Influence of $\mathrm{CO}_{2}$ in Fuel on Engine Parameters. Journal of Middle European Construction and Design of Cars (MECCA), (01/2011): 26-31, 2011. ISSN 1214-0821.

[23] Okamoto, K., Zhang, F.-R., Shimogata, S., and Shoji, F. Development of a Late Intake-Valve Closing (LIVC) Miller Cycle for Stationary Natural Gas Engines - Effect of EGR Utilization. SAE Technical Paper Series, March 1997. Paper 972948, doi: 10.4271/972948.
[24]Sander, U., Menzel, S., and Raindl, M. The New MTU Type L64 of Series 4000 Gas Engines. Proceedings: Conseil International Des Machines A Combustion (CIMAC) Congress 2013, Shanghai, May 2013. Paper No.: 67.

[25]Takats, M. and Macek, J. Vehicle Lean Mixture Gas Engines. Proceedings: Conseil International Des Machines A Combustion (CIMAC) Congress 1993, London, May 1993.

[26] Tinschmann, G., Birgel, A., Trapp, C., Schnessl, E., Redtenbacher, C., and Wimmer, A. Large Gas Engines - 75 mg/ $/ \mathrm{Nm}^{3} @ 15 \% \mathrm{O}_{2} \mathrm{NO}_{x}{ }^{\prime}$ Engine-Internal Measures or Exhaust Aftertreatment?'. Proceedings: Conseil International Des Machines A Combustion (CIMAC) Congress 2013, Shanghai, May 2013. Paper No.: 296.

[27]Trapp, C., Birgel, A., Spyra, N., Kopecek, H., and Chvatal, D. GE's All New J920 Gas engine - a Smart Accretion of Two-stage Turbocharging, Ultra Lean Combustion Concept and Intelligent Controls. Proceedings: Conseil International Des Machines A Combustion (CIMAC) Congress 2013, Shanghai, May 2013. Paper No.: 289.

[28]Trapp, C., Klausner, J., and Lang, J. J624 - der weltweit erste Gasmotor mit zweistufiger Aufladung. MTZ, 2011.

[29]Vítek, 0. and Macek, J. The Influence of Ambient Conditions on a Turbocharged Gas Internal Combustion Engine. In: KoKa 2001, Brno, 2001.

[30]Vítek, 0. and Macek, J. 2-stage Turbocharger Matching for Largebore Gas SI Engine. Internal report for Project FI-IM3/213: Z 06-17, CTU in Prague, Prague, 2006.

[31]Vítek, 0. and Macek, J. Study on 2-stage Turbocharging of Gas SI Engine. Internal report for Project FI-IM3/213: Z 07-05, CTU in Prague, Prague, 2007.

[32]Vítek, 0. and Macek, J. Optimization of 2-stage Turbocharged Large Bore SI Engine. In: KoKa 2008, Brno, [CD-ROM], 2008.

[33]Vítek, 0. and Macek, J. Feasibility of 2-stroke SI Engine Concept using Stoichiometric Mixture. Journal of Middle European Construction and Design of Cars (MECCA), Volume VIII. (01/2010):11-30, 2010. ISSN 1214-0821.

[34]Vítek, O., Macek, J., Doleček, V., Bogomolov, S., Mikulec, A., and Barák, A. Realistic Limits of ICE Efficiency. In: Proceedings of FISITA 2014 [CD-ROM], June 2014. Paper Code: F2014-CET-051.

[35]Vítek, O., Macek, J., and Polášek, M. Simulation of Pre-Chambers in an Engine Combustion Chamber Using Available Software. SAE Technical Paper Series, March 2003. Paper 2003-01-0373, doi: 10.4271/2003-01-0373.

[36]Vítek, O., Macek, J., Polášek, M., Schmerbeck, S., and Kammerdiener, T. Comparison of Different EGR Solutions. SAE Technical Paper Series, April 2008. Paper 2008-01-0206, doi: 10.4271/2008-01-0206. 
[37]Wimmer, A., Pirker, G., Zelenka, J., Chmela, F., Zurlo, J., and Trapp, C. The Potential of Exhaust Gas Recirculation in Large Gas Engines. Proceedings: Conseil International Des Machines A Combustion (CIMAC) Congress 2013, Shanghai, May 2013. Paper No.: 271.

[38]Woschni, G. An Universally Applicable Equation for the Instantaneous Heat Transfer Coefficient in the Internal Combustion Engine. SAE Transactions, Vol. 76:3065, 1967.

[39]Zeldovich, Y. B. The Oxidation of Nitrogen in Combustion and Explosions. In: Acta Physicochim, USSR, 21:557-628, 1946.

\section{ACKNOWLED GMENTS}

This research has been realized using the support of Technological Agency, Czech Republic, Project TA03011212: "Vývoj dvoustupňové plnící skupiny pro velké spalovací motory".

This research has been realized using the support of EU Regional Development Fund in OP R\&D for Innovations (OP $\mathrm{VaVpl}$ ) and The Ministry of Education, Youth and Sports, Czech Republic, project CZ.1.05/2.1.00/03.0125: 'Acquisition of Technology for Vehicle Center of Sustainable Mobility'.

This research has been realized using the support of Technological Agency, Czech Republic, programme Centres of Competence, project TE01020020: 'Josef Božek Competence Centre for Automotive Industry'.

This research has been realized using the support of The Ministry of Education, Youth and Sports program NPU I (LO), project LO1311: 'Development of Vehicle Centre of Sustainable Mobility'.

All the help has been gratefully appreciated.

\section{DEFINITIONS/ABBREVIATIONS}

BBDC Before Bottom Dead Center

BDC Bottom Dead Center

BMEP Brake Mean Effective Pressure

BSFC Brake Specific Fuel Consumption

BTDC Before Top Dead Center

$\operatorname{deg} C A$ Degree of Crank Angle

DoE Design of Experiments

ECU Electronic Control Unit

EGR Exhaust Gas Recirculation

EV Exhaust Valve

EVO Exhaust Valve Opening

FE Finite Element

HP High-Pressure

ICE Internal Combustion Engine

IMEP Indicated Mean Effective Pressure

IV Intake Valve

IVC Intake Valve Closing

IVO Intake Valve Opening

LP Low-Pressure

MBF Mass Burned Fraction

MEP Mean Effective Pressure

PID Proportional-Integral-Derivative controller

PMEP Pumping Mean Effective Pressure

PR Pressure Ratio

ROHR Rate of Heat Release

SI Spark Ingintion

SCR Selective Catalytic Reduction

TA Luft legislative norm to limit emission of $\mathrm{NO}_{x}$; the air excess was controlled in such way that $\mathrm{NO}_{x}$ should satisfy the TA Luft requirement

TDC Top Dead Center

VGT Variable Geometry Turbine/Turbocharger (the same as VTA, which is used in some papers and reports)

WG Waste-Gate 


\section{INFLUENCE OF COMBUSTION DURATION}

The main goal of presenting this section is to support the statement from Chapter 3, that 'the authors are convinced that EGR rate has minor influence on optimization of boost group and selection of both proper control and EGR configuration'. Three different combustion duration cases were tested (c.f. Figure 18). The reference combustion duration (blue curve in Figure 18), which was applied in all cases presented in the paper (Figures $6-17)$. The combustion duration is 28 degCA from MBF10\% to $\mathrm{MBF} 90 \%$ and Vibe exponent is 2.0, which corresponds to duration of 43.6 degCA to burn $90 \%$ of the fuel in the cylinder. Such combustion duration is in-line with the authors experience with similar engines. Moreover it corresponds well to measured data from [37] (c.f. Figure 19), when very similar engine was experimentally investigated under similar operating conditions (BMEP 22 bar at TA Luft 100\%). To show sensitivity of predicted results with respect to combustion duration, 30\% faster combustion (red curve in Figure 18) and 30\% slower combustion (green curve in Figure 18) were tested.

The first step was to perform the whole optimization procedure (c.f. Chapter 4.3) for faster/slower combustion cases as well. The optimal values of HP/LP compressor/turbine multipliers, which are always the outputs of the optimization procedure, are shown in Figure 21 - different cases in terms of required EGR/ TA Luft level and/or applied EGR configuration (LP EGR or HP $E G R+E G R$ compressor) were tested. Optimal turbocharger configuration in terms of mass-flow multipliers is usually independent of combustion duration. This is especially valid for reference and slower combustion duration (c.f. Figure 21).

(a) rate of heat relaese

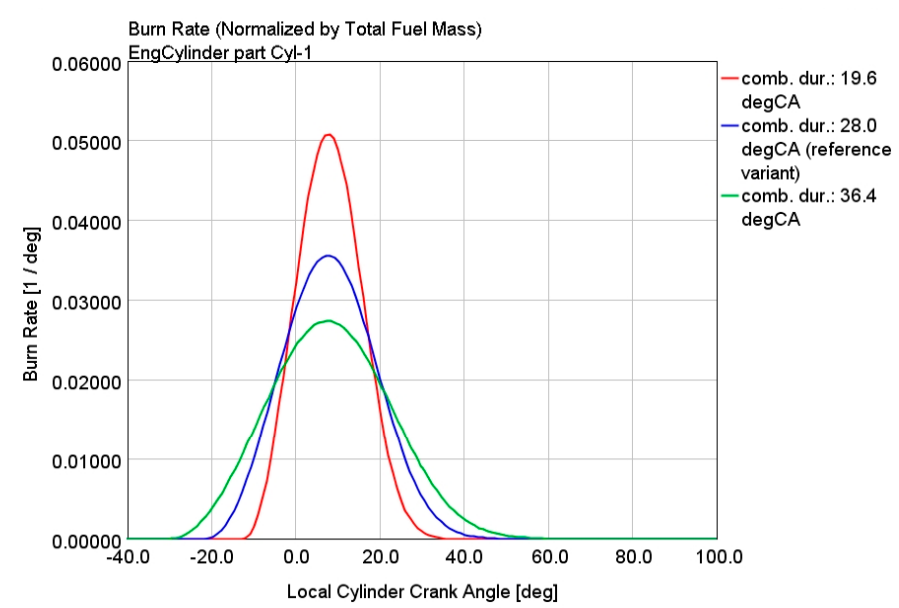

This statement is verified in Figure 22, which shows the influence of applied turbocharger group in terms of BSFC. Each subFigure in Figure 22 presents 4 curves. The dark-blue curve corresponds to a case when HP/LP compressor/turbine multipliers are optimized for each considered combustion duration (label opt_MF_mult) using information from Figure 21, while combustion phasing is constant (label const_ comb_pos) corresponding to subFigure (b) of Figure 18 - this means that angle location of MBF50\% is 8 degCA. The pink curve represents a case when constant mass-flow multipliers are applied - the applied multiplier values correspond to reference combustion duration from Figure 21. Concerning the combustion timing, the same constant approach (const_ comb_pos) was adopted. The light-green curve shows a case when optimal turbochargers are applied for each combustion duration (opt_MF_mult), however, combustion timing was optimized as well (label opt_comb_pos) to obtain the lowest possible BSFC. Finally, the light-blue curve represents a case when constant mass flow multipliers are applied (const comb_pos), while optimized combustion timing approach (opt_comb_pos) was adopted. The relative difference between 2 selected curves in Figure 22 shows the specific influence. For example, the difference between the dark-blue curve and the pink one confirms that applying reference optimal turbocharger configuration, which corresponds to a reference combustion duration, leads to a BSFC difference in order of $0.1 \mathrm{~g} / \mathrm{kW} / \mathrm{h}$ when compared with optimal configurations of faster/slower combustion duration. Another example shows, that applying

(b) heat release

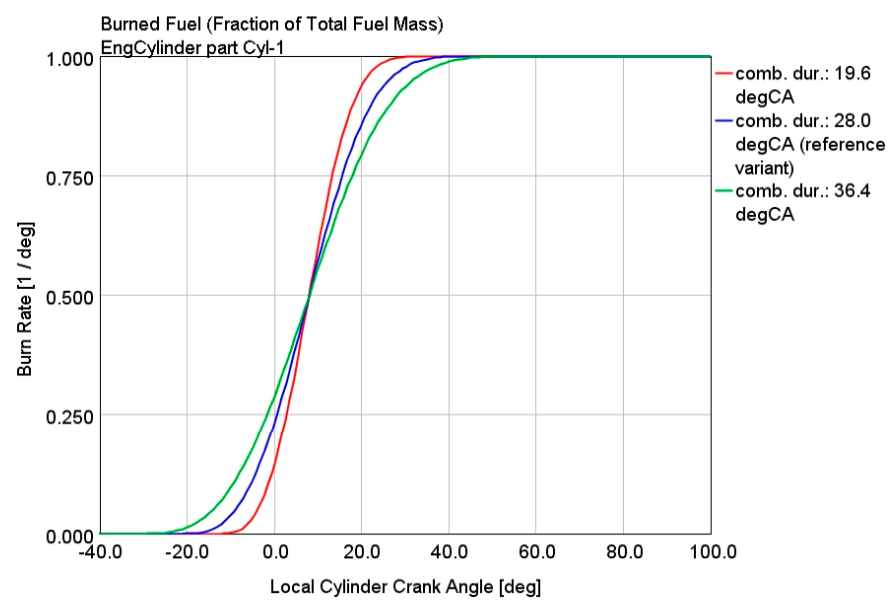

FIGURE 18: Comparison of different ROHR patterns (dark-blue curve corresponds to reference variant). OBRÁZEK 18: Porovnání různých tvarů vývinů tepla (tmavě modrá barva reprezentuje referenční variantu). 

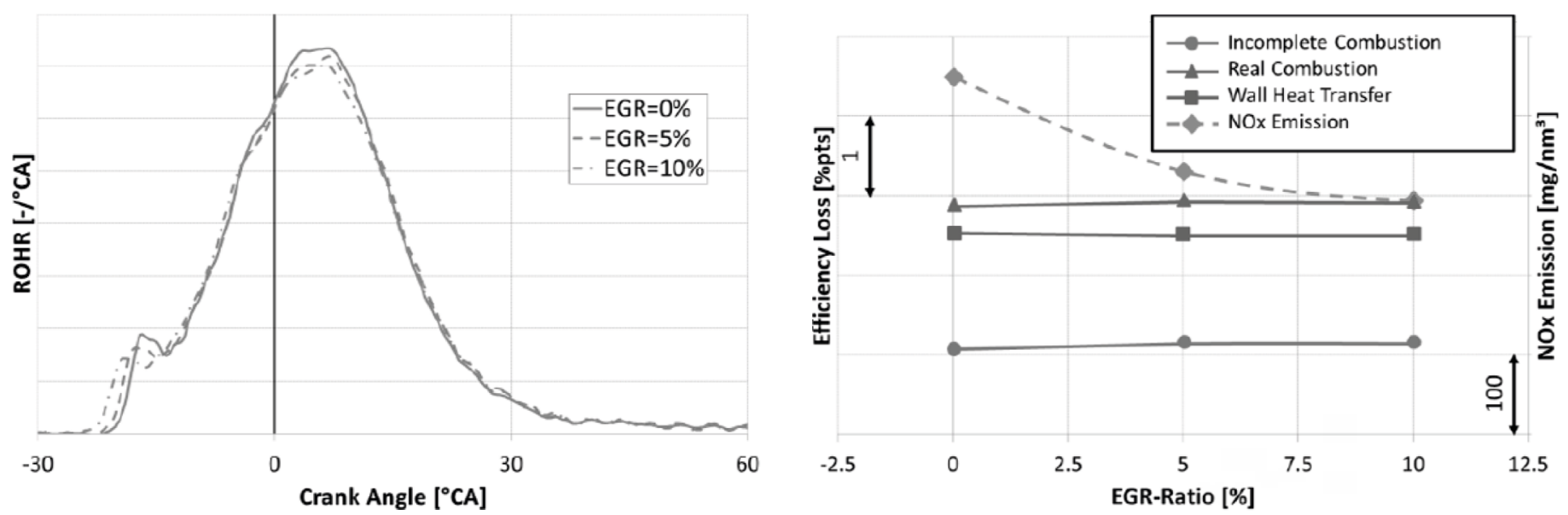

FIGURE 19: Influence of external EGR on ROHR and NOx formation - experimental data from single-cylinder research engine (the plots were reprinted from [37]). OBRÁZEK 19: Vliv vnější recirkulace (EGR) na vývin tepla (ROHR) a tvorbu NOx - experimentální data z výzkumného jednoválce (obrázky převzaty z [37]).

(a) air excess at constant NOx levels

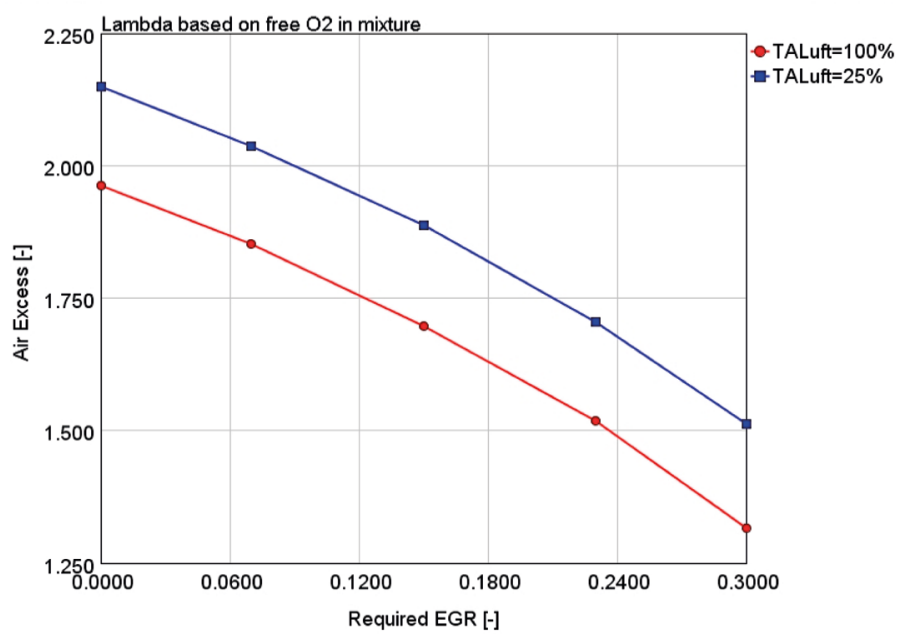

(b) air excess at constant EGR levels

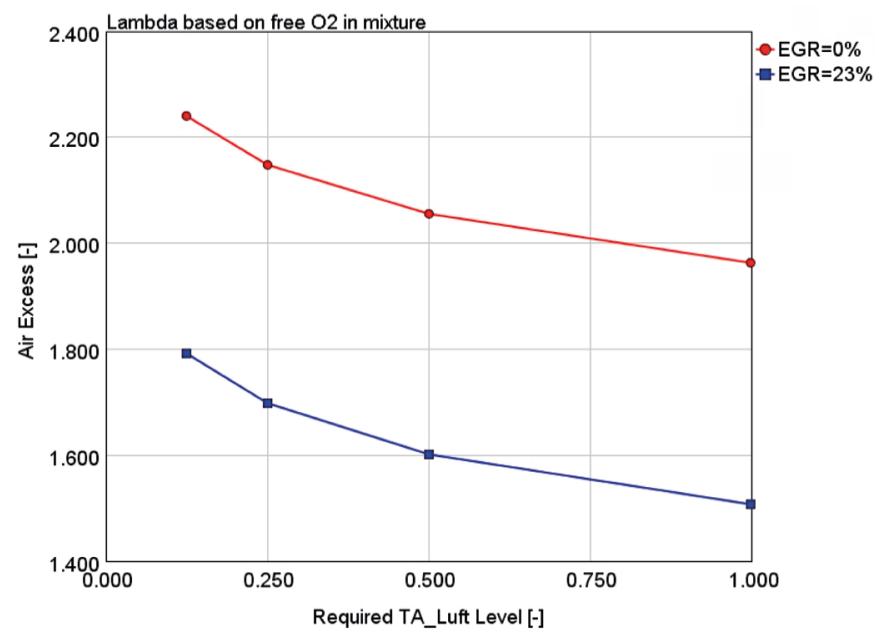

FIGURE 20: Air excess based on free 02 mass - the plots correspond to data presented in Figure 23.

OBRÁZEK 20: Přebytek vzduchu založen na volném kyslíku - grafy odpovídají datům z Obrázku 23.

constant combustion timing leads to almost no BSFC difference when compared with optimal one (compare dark-blue curve with light-green one). Based on data from Figure 21 and Figure 22, there is very little influence of combustion duration and combustion timing on optimal values of HP/LP compressor/ turbine mass-flow multipliers. Of course, there is always a BSFC penalty (c.f. Figure 22) associated with increased combustion duration - this penalty is almost independent of required EGR/ TA Luft level and/or applied EGR configuration. It should be stressed that there are certain cases in Figure 22 when there is a sudden increase in BSFC when faster combustion duration is considered - light-green curve in subFigure (c) or pink curve in subFigure (e). This corresponds to a fact that required BMEP of 24 bar cannot be reached, hence additional BSFC penalty is applied.

Additionally, there is an open issue if combustion duration is really supposed to be increased when changing requirement of EGR/TA Luft level. There is an experimental evidence from [37] (c.f. subFigure (a) of Figure 19) that combustion duration and its shape is almost independent of applied external EGR level. However, the pre-chamber concept is applied in [37] the first little peak of ROHR in subFigure (a) of Figure 19 is caused by combustion in pre-chamber. Concerning ignition system, there were no specific assumptions concerning 
(a) TA Luft $=100 \%, E G R=0 \%$

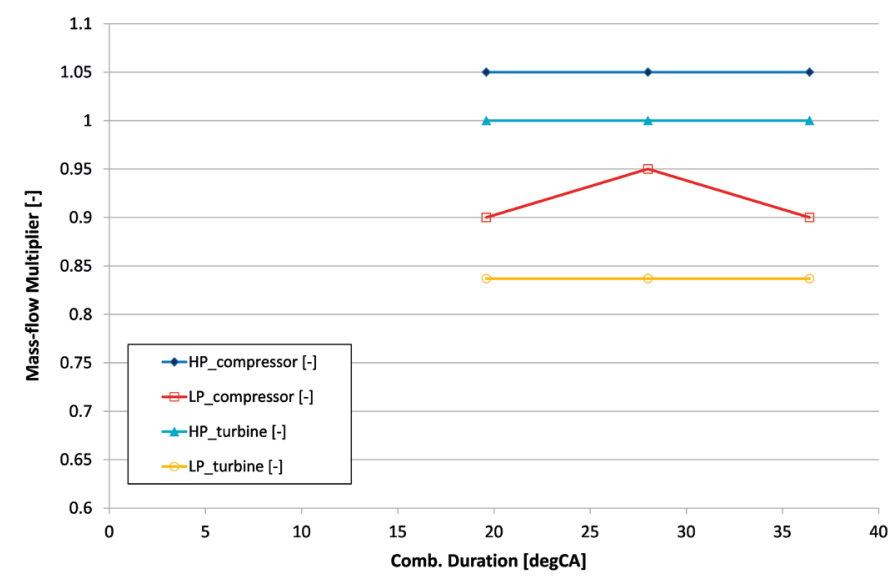

(c) TA Luft $=100 \%$, HP EGR + EGR compressor, EGR $=23 \%$

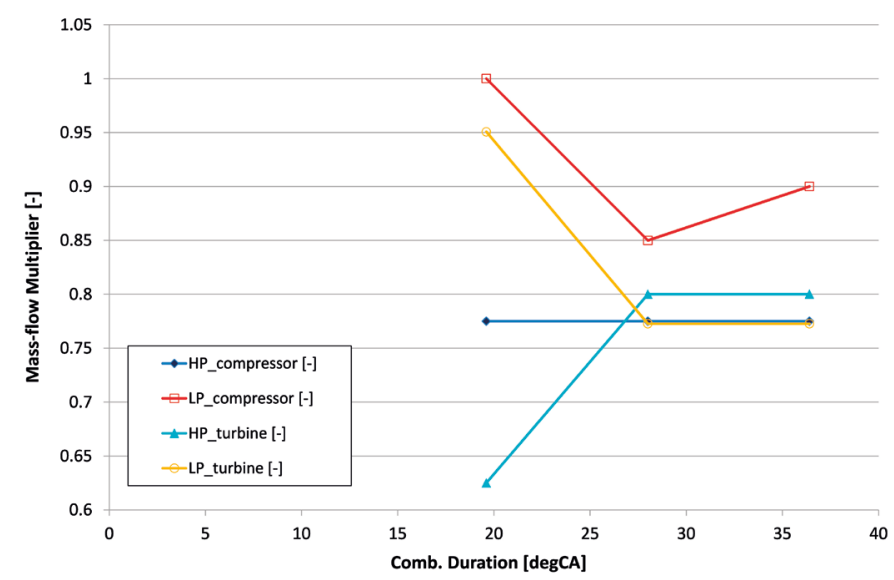

(e) $\mathrm{TA}$ Luft $=100 \%$, LP EGR, EGR $=23 \%$

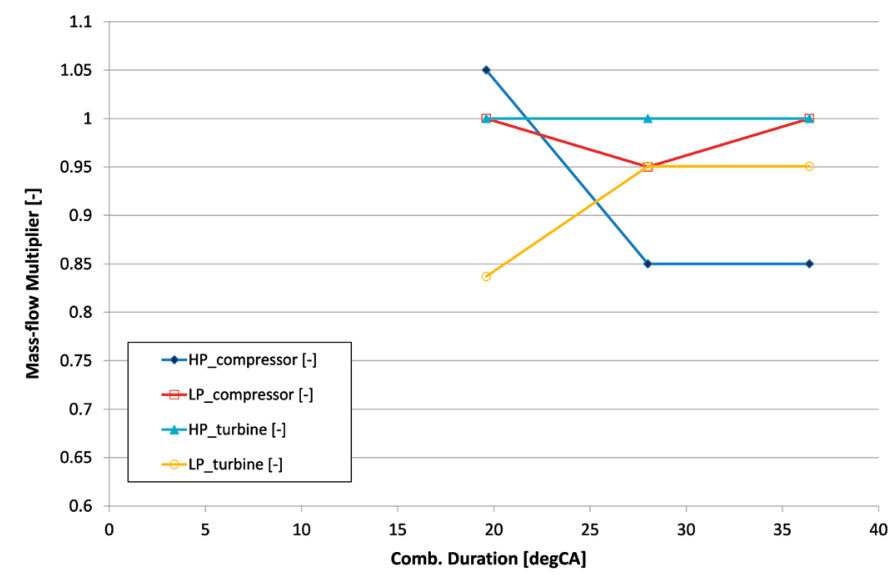

(b) $T$ A Luft $=25 \%, E G R=0 \%$

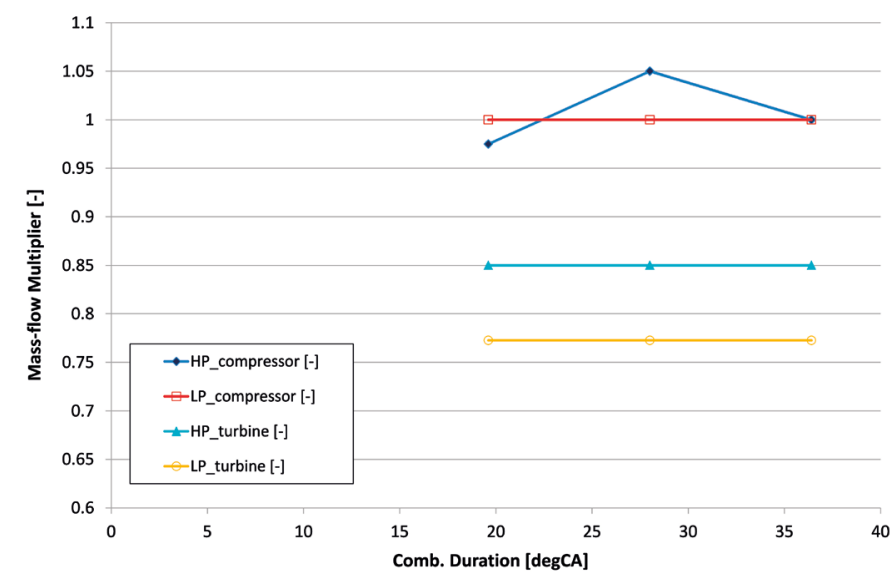

(d) $T A$ Luft $=25 \%, H P E G R+E G R$ compressor, $E G R=23 \%$

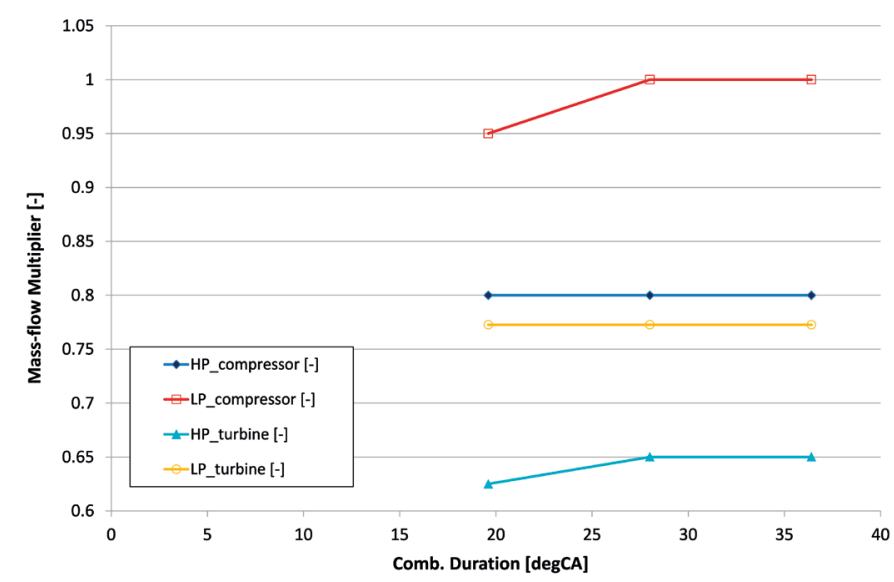

(f) $T A$ Luft $=25 \%, L P E G R, E G R=23 \%$

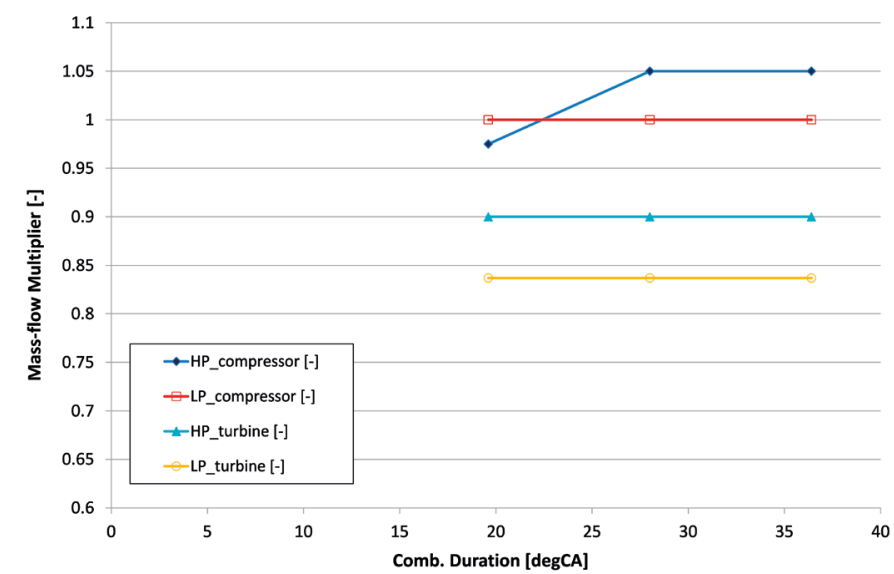

FIGURE 21: Influence of combustion duration under steady operation - optimal mass-flow multipliers of HP/LP compressor/turbine; engine setting: blow-by $=5 \%$, BMEP $=24$ bar, const comb. timing (MBF50\% at 8 degCA after TDC).

OBRÁzEK 21: Vliv délky hoření za ustálených podmínek - optimální velkost vysoko-a nízkotlakého kompresoru a turbiny; nastavení: blow-by = 5\%, BMEP = 24 bar, konstantní časování hoření ( $50 \%$ bod je v 8 stupních za horní úvratí). 
the target engine (Table 1). The large-bore $\mathrm{SI}$ gas engines, which are operated under lean-burn conditions, have to be equipped with high-energy ignition system to enable reliable mixture ignition. It is wellknown that application of pre-chamber concept can provide that (c.f. [24-27, 37]), especially if there is a possibility to add additional fuel into the pre-chamber [35]. In any case, large-bore SI gas engines are less sensitive to mixture composition changes due to application of high-energy ignition system.

Based on the above mentioned facts, it was decided to plot important in-cylinder quantities for different engine operating conditions - this is shown in Figure 23. Different conditions were tested to take into account different EGR/ TA Luft levels. For each operating condition, there are 2 subfigures in Figure 23 - the left one shows mass fractions of selected in-cylinder species while the right one presents total in-cylinder mass of these species.

The virtual measurement was done at $60 \operatorname{deg} C A$ before TDC. The influence of both required EGR level and TA Luft are shown. When considering the case of constant TA Luft level and varying EGR level, the following can be stated. As EGR increases, the mass fraction of $\mathrm{CO}_{2}$ is increased while $\mathrm{O}_{2}$ decreases, the same applies to mass amount of both considered species. The mass fraction of $\mathrm{N}_{2}$ is almost constant while $\mathrm{N}_{2}$ mass slightly decreases. This is caused by the fact that total in-cylinder mass slightly decreases. The fuel mass fraction/amount is almost constant due to the fact that required BMEP is the same (24 bar) and BSFC is very similar for all presented cases. The air excess, which is based on free $\mathrm{O}_{2}$, is shown in subFigure (a) of Figure 20. Regarding the case of constant EGR level and varying $T A$ Luft level, the trends are the following. The mass fraction of $\mathrm{CO}_{2}, \mathrm{O}_{2}$ and $\mathrm{N}_{2}$ is constant while fuel mass fraction decreases as TA Luft requirement gets stricter (lower value of TA Luft parameter, which is plotted on $x$-axis) - this leads to higher air excess (c.f. subFigure (b) of Figure 20). In-cylinder mass increases for all considered species.

Considering all presented information, it seems that keeping TA Luft requirement constant while varying EGR level leads to relatively similar in-cylinder conditions in terms of important species. Certain amount of free $\mathrm{O}_{2}$ is replaced by $\mathrm{CO}_{2}$, however, its mass fraction is less than $5 \%$ due to relatively high air excess. Although air excess changes significantly (c.f. subFigure (a) of Figure 20), the mixture is still very lean and the amount of the mass-dominant specie, which is $N_{2}$, is changed only slightly. Hence, the negative effect of high EGR is compensated by lower air excess. This suggests that laminar flame front propagation speed may be changed slightly as well. If the ignition system is able to ignite the mixture reliably, then the main combustion phase is expected to proceed normally - this is driven by turbulent flame front propagation. Hence, no major changes of ROHR duration/shape can be expected - this is confirmed by results in [37]. Moreover, the work presented in $[21,22]$, which is available at the authors' department, provides similar suggestions. However, the data, which were used for creating a correction functions to recalculate a ROHR model parameters, do not cover a region of very high air excess and high EGR rate. Hence the application of the model $[21,22]$ for the case of the target engine is not directly possible due to the fact that extrapolation outside of the calibration data is necessary. On the other hand, the author of $[21,22]$ is convinced that the qualitative trend is predicted correctly - the model suggests that the combustion duration is supposed to be changed only slightly for the cases of constant TA Luft and varying EGR level (subFigure (a) of Figure 20 and subfigures (a), (b), (c) and (d) of Figure 23). When dealing with the case of constant EGR level while varying TA Luft requirement, the following can be stated. The mass fraction of major species $\left(\mathrm{CO}_{2}, \mathrm{O}_{2}\right.$, $\mathrm{N}_{2}$ ) is almost constant while fuel fraction decreases when TA Luft requirement gets stricter. This leads to significant increase in air excess (c.f. subFigure (b) of Figure 20). This fact together with increased total mass leads to conclusion that such case is more likely to exhibit slower combustion. This is also confirmed by the model based on [21,22].

When applying ROHR with constant parameters (duration, phasing and shape), there is one important advantage which is difficult to achieve on a real engine. Constant ROHR actually means that the predicted BSFC is not directly influenced by combustion model, hence the influence of all other phenomena is highlighted. This is actually desired as the influence of different operating conditions is of main interest (c.f. Chapter 2).

Final comment concerns the results presented in the paper, which corresponds to Figures $6-17$. Based on the above mentioned facts, the combustion duration may be important when comparing the results with different $\mathrm{NO}_{x}$ levels (different TA Luft requirements). This is only shown in Figure 16. However, the qualitative trends remain unchanged as stricter $\mathrm{NO}_{x}$ leads to higher BSFC even if constant ROHR is assumed. Hence, possibly longer combustion would result in greater BSFC differences only - the qualitative comparison would be the same. There is a possibility that high EGR cases (EGR $>15 \%)$ might be also influenced by slower combustion. If it is the case, the qualitative trends (c.f. Figure 11-16) would also be unchanged as the optimal EGR levels are relatively low (below $10 \%$ - c.f. Figure 17 ). 
(a) $\mathrm{TA}$ Luft $=100 \%, E G R=0 \%$

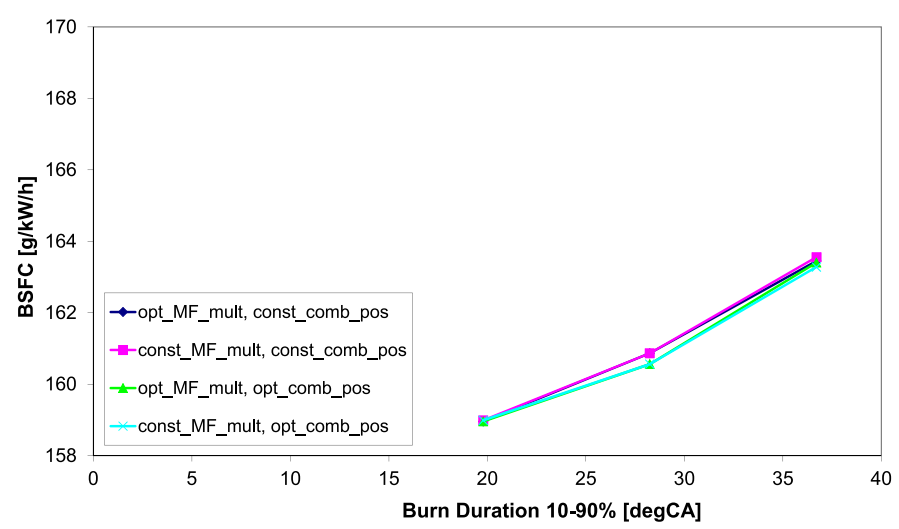

(c) TA Luft $=100 \%$, HP EGR + EGR compressor, EGR $=23 \%$

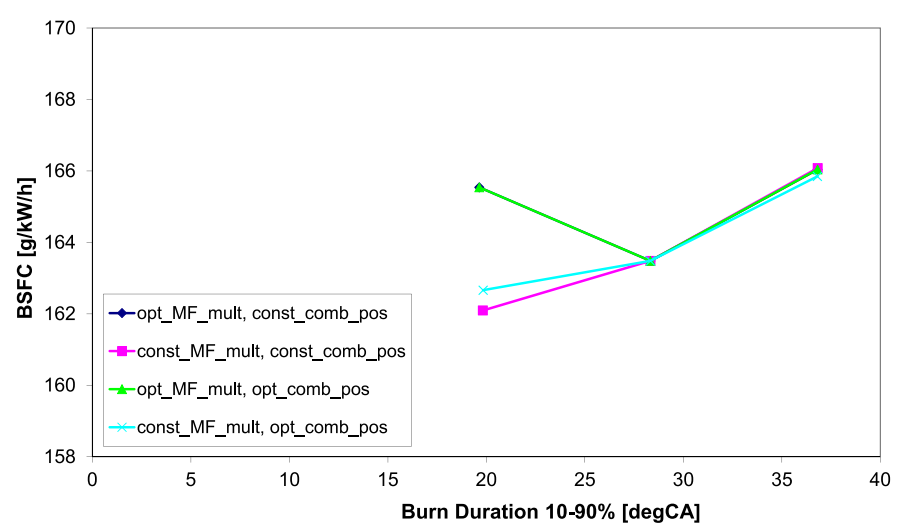

(e) $\mathrm{TA}$ Luft $=100 \%$, LP EGR, EGR $=23 \%$

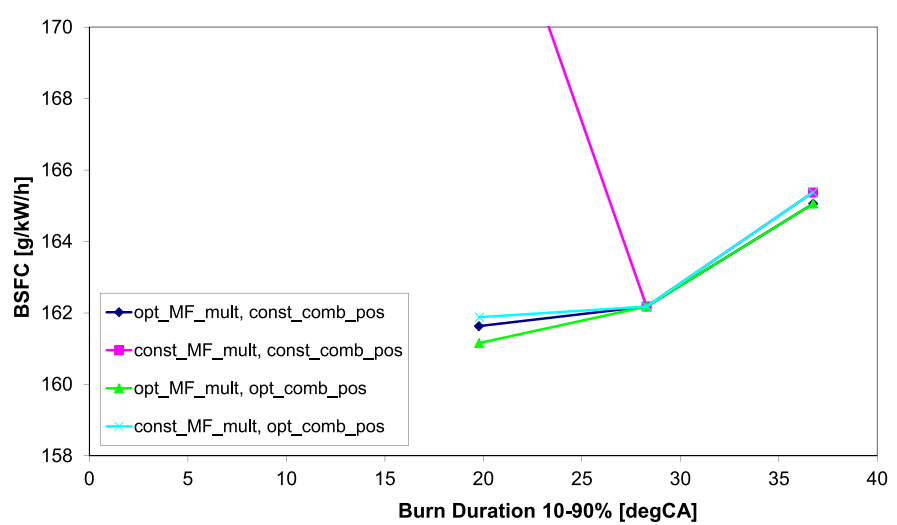

(b) $T A$ Luft $=25 \%, E G R=0 \%$

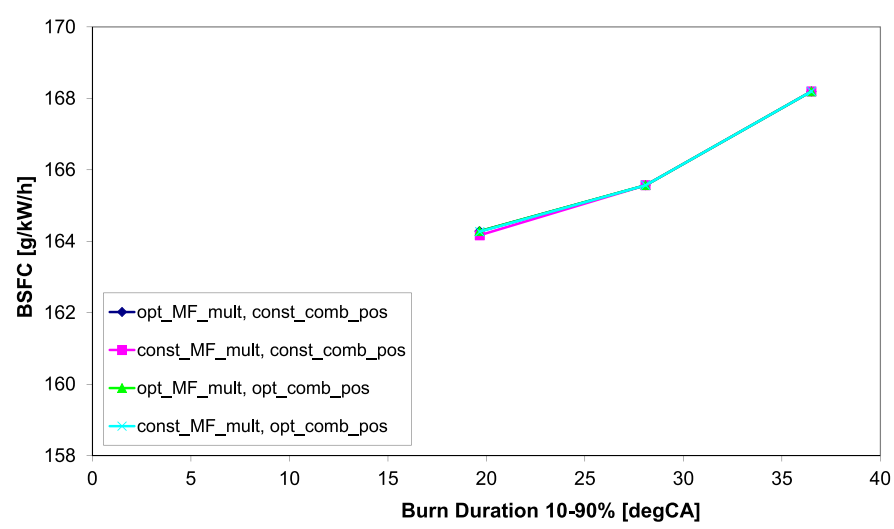

(d) $T A L u f t=25 \%, H P E G R+E G R$ compressor, $E G R=23 \%$

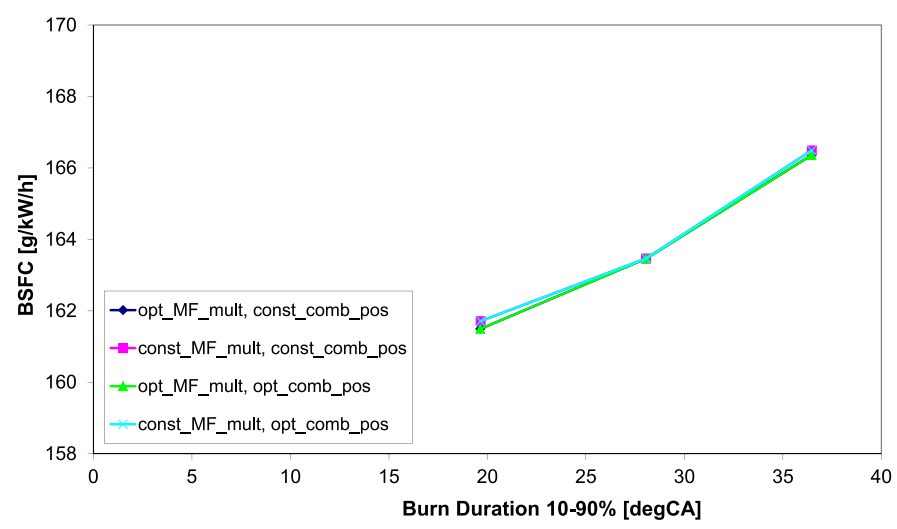

(f) $T A$ Luft $=25 \%$, LP EGR, EGR $=23 \%$

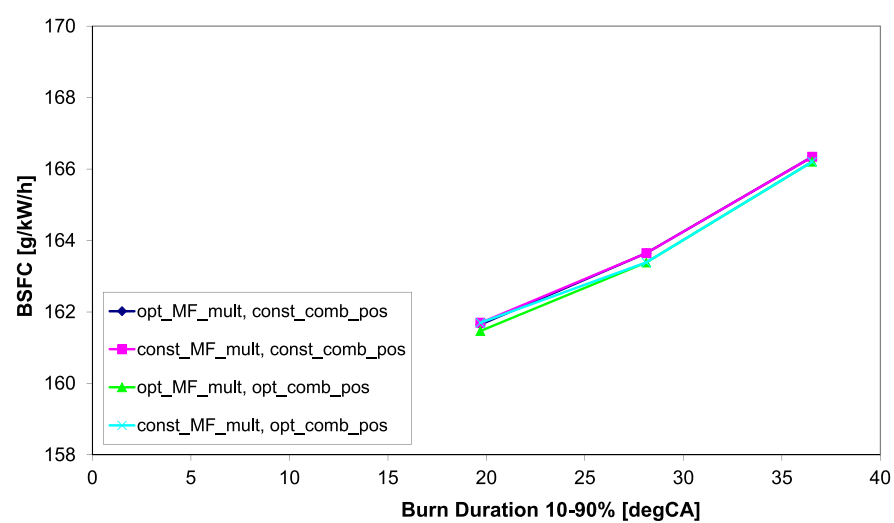

FIGURE 22: Influence of combustion duration under steady operation - BSFC for different cases of applied mass-flow multipliers (Figure legend: 'opt_ MF_mult' - mass-flow multipliers of HP/LP compressor/turbine optimized for each combustion duration - c.f. Figure 21; 'const_MF_mult' - constant mass-flow multipliers corresponding to optimal values at combustion duration of 28.2 degCA; 'opt_comb_pos' - combustion timing optimized for best BSFC; 'const_comb_pos' - constant combustion timing: MBF50\% at 8 degCA after TDC); engine setting: blow-by $=5 \%, B M E P=24 b a r$. OBRÁZEK 22: Vliv délky hoření za ustálených podmínek - měrná spotřeba paliva pro různé hltnosti (legenda: 'opt_MF_mult' - velikosti odpovídající Obrázku 21; 'const_MF_mult' - konstantní hltnost odpovídající délce hoření 28.2 stupně; 'opt_comb_pos' - optimalizovan8 poloha hoření pro nejlepší spotřebu; 'const_comb_pos' - konstantní poloha hoření: $50 \%$ bod v 8 stupních za horní úvratí); nastavení: blow-by = 5\%, BMEP = 24 bar. 
(a) TA Luft $=100 \%$ : mass fraction

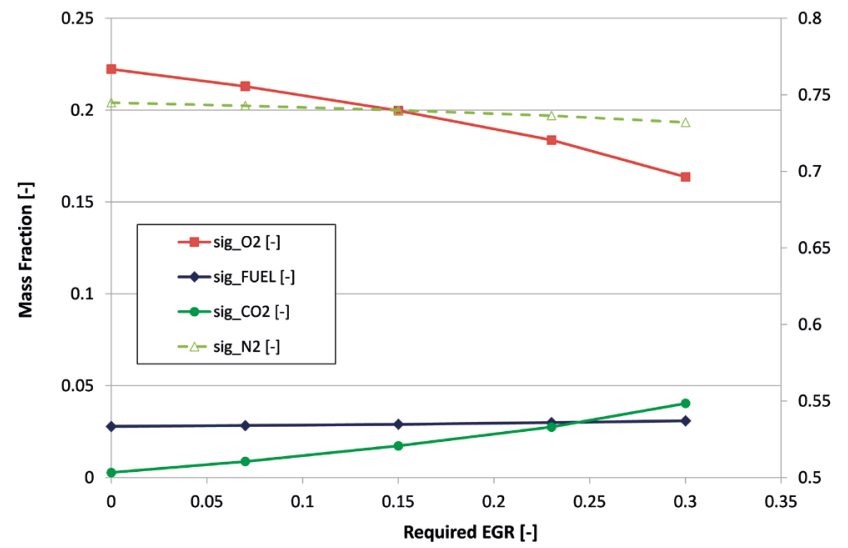

(c) $T A$ Luft $=25 \%:$ mass fraction

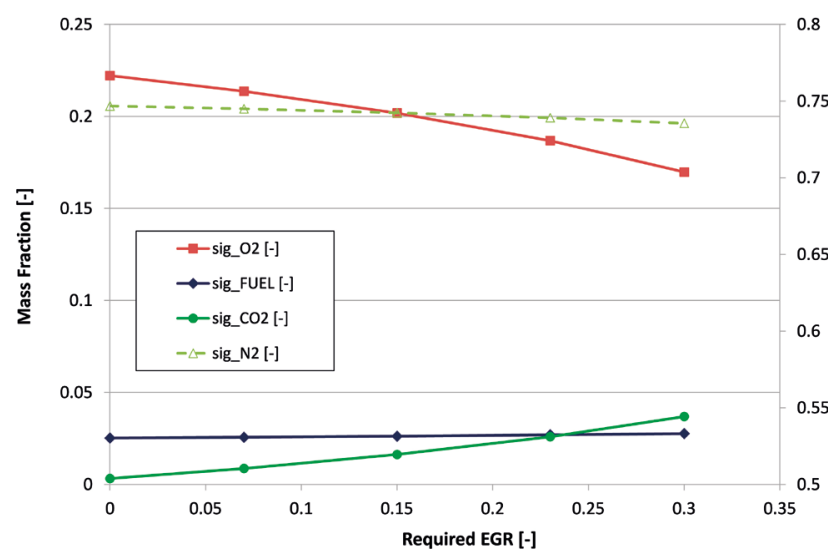

(e) $E G R=0 \%:$ mass fraction

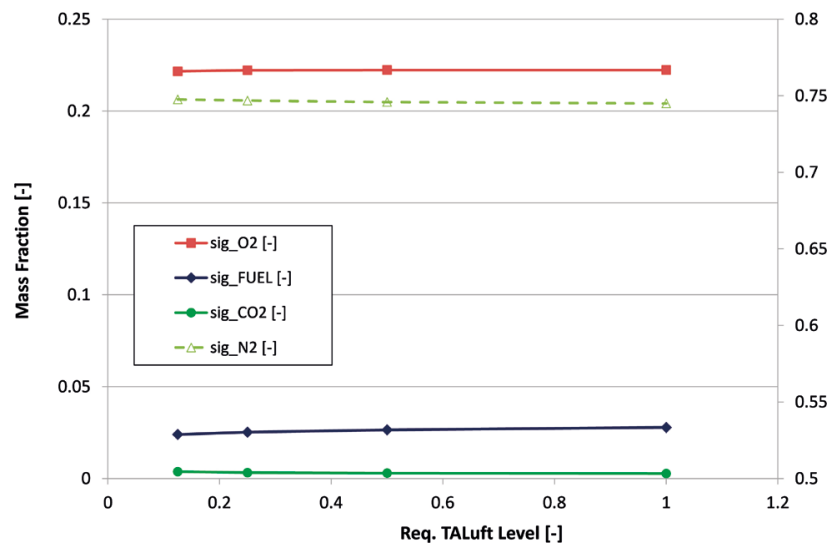

(b) TA Luft $=100 \%:$ mass

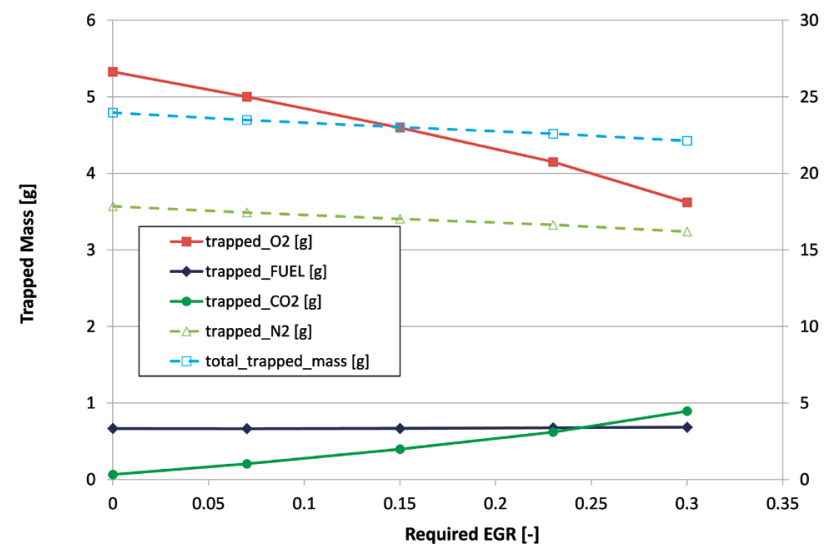

(d) TA Luft $=25 \%:$ mass

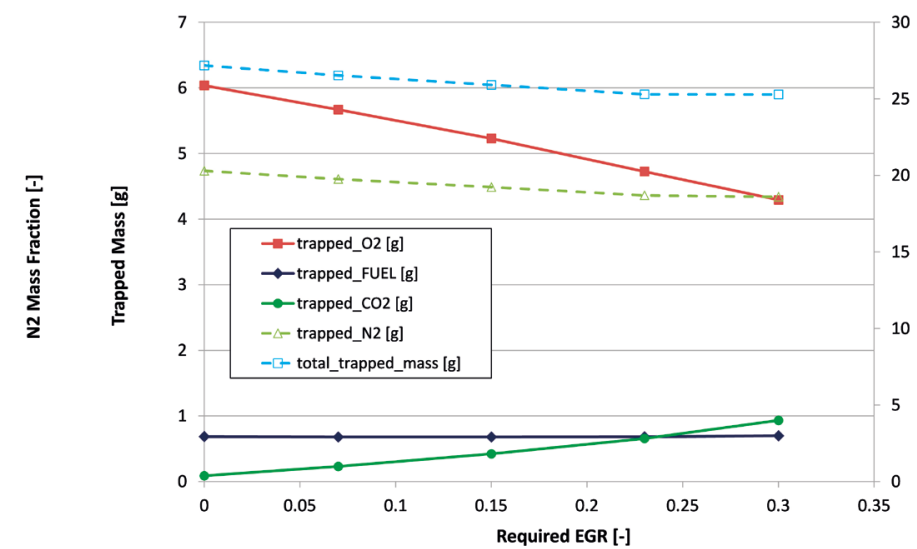

(f) $E G R=0 \%:$ mass

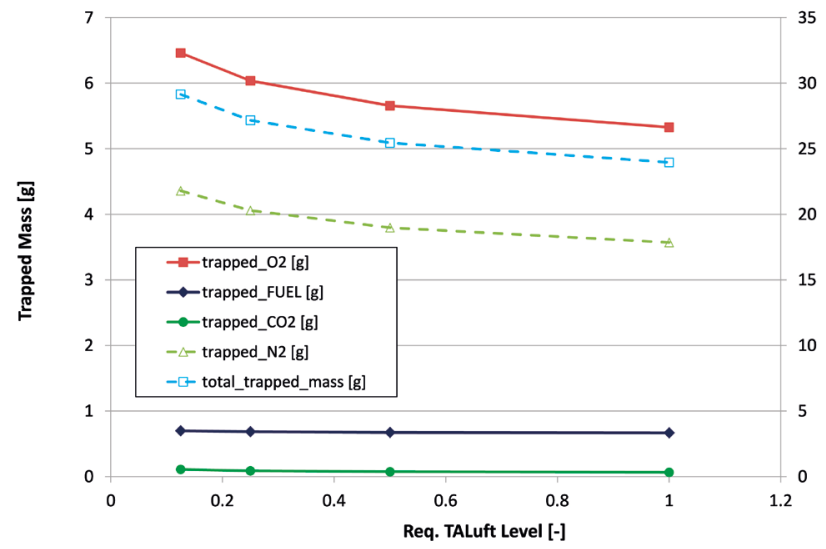

FIGURE 23: Comparison of in-cyclinder species content with respect to different EGR level or TA Luft level; engine setting: blow-by = 5\%, $L P E G R$. OBRÁZEK 23: Srovnání složení vybraných složek ve válci pro různé úrovně EGR nebo různé úrovně NOx (dle TA Luft); nastavení: blow-by = 5\%, varianta LP EGR. 